
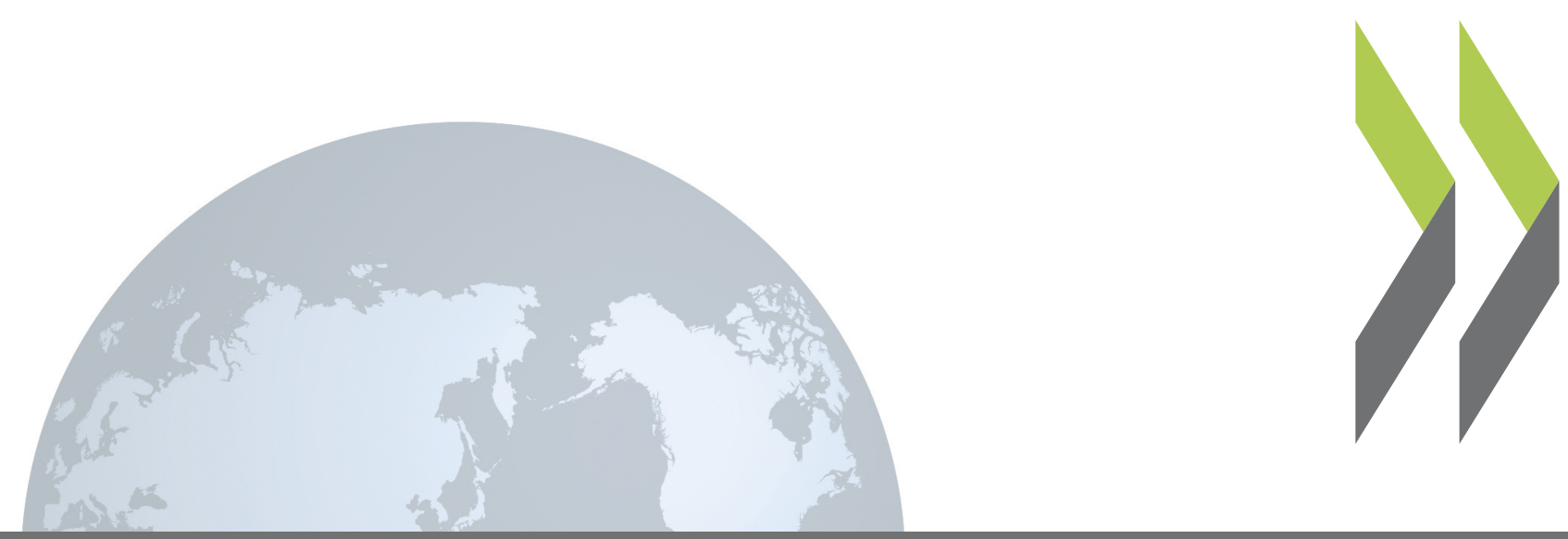

OECD Regional Development Working Papers 2014/02

A Sub-national Perspective on Financing Investment for Growth I - Measuring Fiscal Space for Public

\title{
Claudia Hulbert,
} Investment: Influences, Evolution and Perspectives 

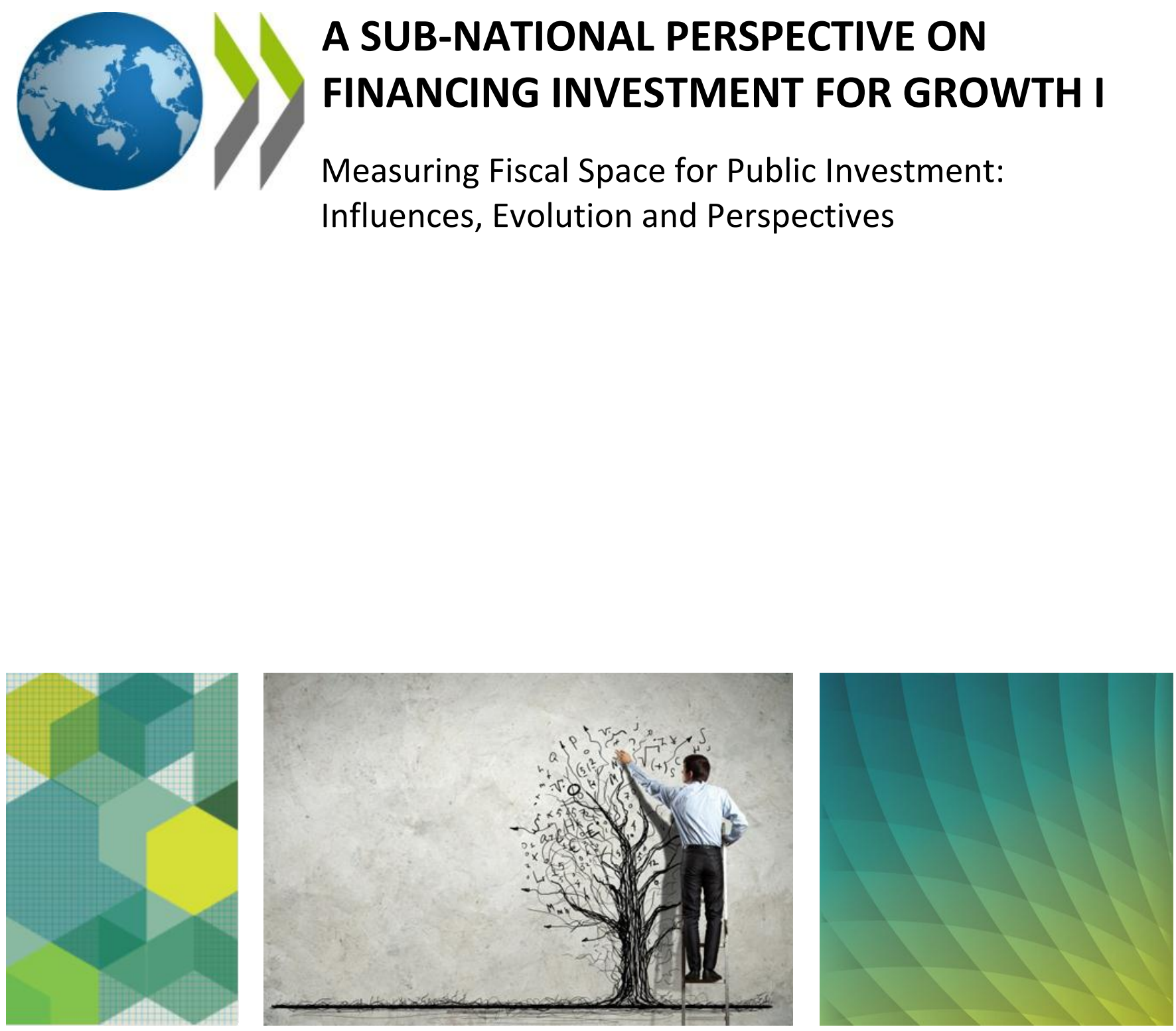


\section{OECD REGIONAL DEVELOPMENT WORKING PAPERS}

This series is designed to make available to a wider readership selected studies on regional development issues prepared for use within the OECD. Authorship is usually collective, but principal authors are named. The papers are generally available only in their original language English or French with a summary in the other if available.

OECD Working Papers should not be reported as representing the official views of the OECD or of its member countries. The opinions expressed and arguments employed are those of the author(s).

This document has been produced with the financial assistance of the European Union. The views expressed herein can in no way be taken to reflect the official opinion of the European Union.

The statistical data for Israel are supplied by and under the responsibility of the relevant Israeli authorities. The use of such data by the OECD is without prejudice to the status of the Golan Heights, East Jerusalem and Israeli settlements in the West Bank under the terms of international law.

Working Papers describe preliminary results or research in progress by the author(s) and are published to stimulate discussion on a broad range of issues on which the OECD works. Comments on Working Papers are welcomed, and may be sent to either gov.contact@oecd.org or the Public Governance and Territorial Development Directorate, OECD, 2 rue André-Pascal, 75775 Paris Cedex 16, France.

Authorised for publication by Rolf Alter, Director, Public Governance and Territorial Development Directorate, OECD.

OECD Regional Development Working Papers are published on http://www.oecd.org/gov/regional/workingpapers

Applications for permission to reproduce or translate all or part of this material should be made to: OECD Publishing, rights@oecd.org or by fax 33145249930.

(C) OECD 2014

Photo credits:

(C) Sergey Nivens/Shutterstock.com, () nanano/Shutterstock.com, ( newcorner/Shutterstock.com 


\title{
A SUB-NATIONAL PERSPECTIVE ON FINANCING INVESTMENT FOR GROWTH I
}

\section{MEASURING FISCAL SPACE FOR PUBLIC INVESTMENT: INFLUENCES, EVOLUTION AND PERSPECTIVES}

\author{
By Claudia Hulbert and Camila Vammalle ${ }^{1}$
}

\begin{abstract}
:
Sub-national governments are key players for public investment, as they are responsible on average for $62 \%$ of total public investment in OECD countries. This article analyses the different factors affecting sub-national governments' fiscal space for public investment. It proposes an indicator for measuring this fiscal space and analyses the evolution of its different components over 2007-2012. The article shows that the global financial crisis and the ensuring consolidation drive have reduced sub-national governments' fiscal space for public investment, through a downward pressure on revenues, increased expenditure obligations, and constrained capacity to borrow or issue debt on financial markets.

\section{Résumé :}

Les gouvernements infra-nationaux sont des acteurs majeurs de l'investissement public dans les pays de l'OCDE, et représentent en moyenne $62 \%$ de l'investissement public total. Cet article analyse les déterminants de la marge de manœuvre budgétaire disponible pour l'investissement public infranational. Il propose un indicateur pour mesurer cette marge de manœuvre, et analyse l'évolution de ses composantes entre 2007 et 2012. La crise et les plans de rigueur introduits dans de nombreux pays ont réduit l'espace budgétaire des gouvernements infra-nationaux disponible pour l'investissement. Ceci s'explique à la fois par une baisse des revenus infra-nationaux, une hausse des dépenses ainsi que par une plus grande limitation dans leur accès à l'emprunt bancaire ou à l'emprunt sur les marchés financiers.
\end{abstract}

1. The authors are indebted to Rudiger Ahrend, Dorothée Allain-Dupré, Claire Charbit, Isabelle Chatry, Paul Bernd Spahn and Bill Tompson for their valuable comments and inputs. 


\section{TABLE OF CONTENTS}

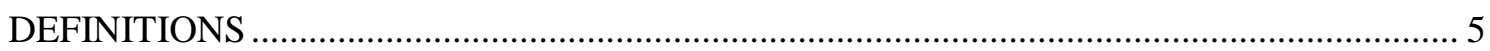

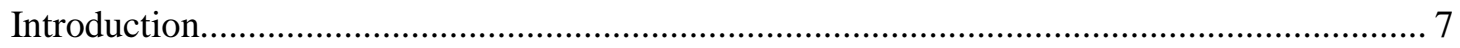

I. SNGs' growing role in financing public investment ........................................................... 9

II. Direct financial capacity: an indicator of SNG fiscal space for public investment............. 14

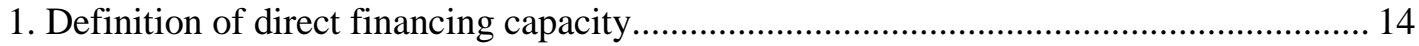

2. Evolution of sub-national government direct financing capacity .................................... 15

3. Factors affecting sub-national governments' direct financing capacity ............................ 19

III. Factors influencing SNGs' ability to borrow to finance investment .................................. 24

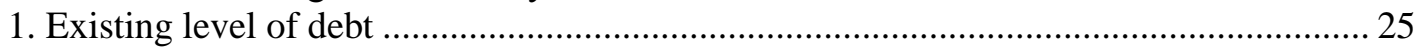

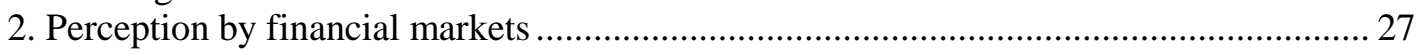

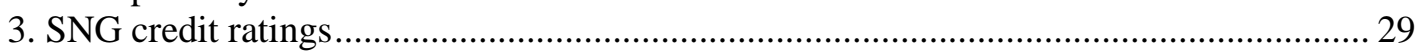

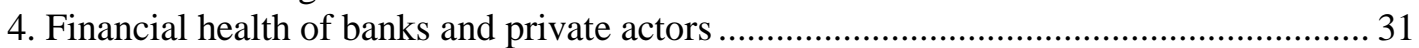

IV. The impact of recent fiscal policies on SNGs' financial capacity for investment............. 32

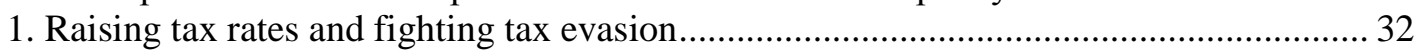

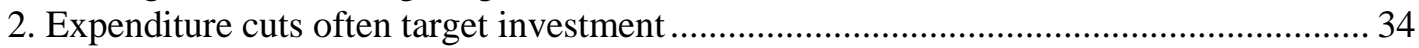

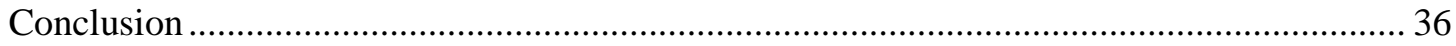

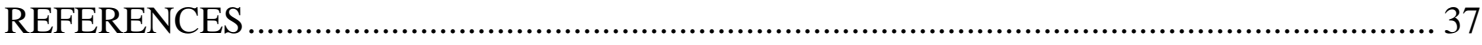

ANNEX 1 - EVOLUTION OF THE COMPONENTS OF SNG REVENUES .......................... 40

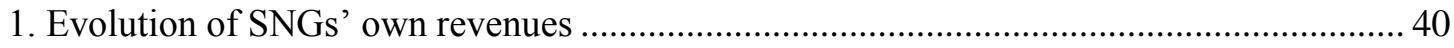

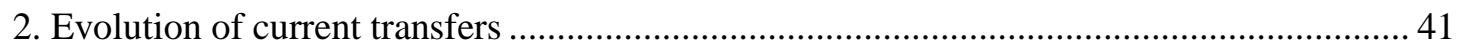

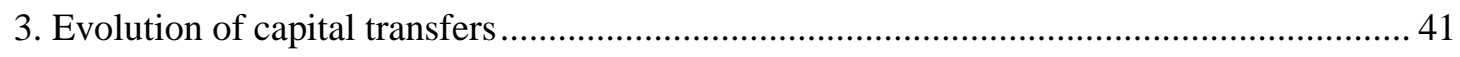

\section{Tables}

Table 2. Sub-national government expenditure reduction targets 34

\section{Figures}

Figure 1. Variations in private and public GFCF in OECD countries (in \%) .......................... 7

Figure 2. SNG share in general governments' revenues and expenditures (2011) ................... 9

Figure 3. Sub-national share of public investment (2011) ................................................. 10

Figure 4. Evolution of the sub-national share of public investment in selected countries....... 10

Figure 5. Changes in the share of SNGs in total public investment (2007-2011) ................... 11

Figure 6. Average public investment per capita in OECD Countries ...................................... 12

Figure 7. Changes in total public investment between 2007 and 2011............................... 12

Figure 8. Changes in per capita public investment in selected countries (2007-2011)............ 13

Figure 9. SNG public investment as a share of expenditures ................................................ 13

Figure 10. Relation between SNG direct financing capacity and public investment .............. 15

Figure 11. Direct financing capacity per capita as a share of SNG revenues (2005-2011) ..... 16

Figure 12. SNG direct financing capacity as a share of revenues.......................................... 18

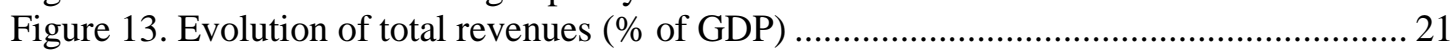

Figure 14. Evolution of total revenues per capita (2007-2011) ............................................. 21 
Figure 15. Evolution of operating expenditures as a share of GDP (2005-2010)................... 22

Figure 16. Evolution of operating expenditures per capita (2007-2010) ................................. 22

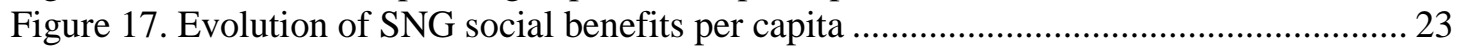

Figure 18. Evolution of current transfers paid by SNGs per capita)...................................... 23

Figure 19. Dispersion of GDP per capita within countries (TL2 regions) ............................... 24

Figure 20. Dispersion of average annual regional GDP growth (TL2 regions) ...................... 24

Figure 21. Composition of public debt as a share of GDP (2012) ....................................... 26

Figure 22. Dispersion of SNG debt to revenues in TL2 regions (2007-2010)........................ 26

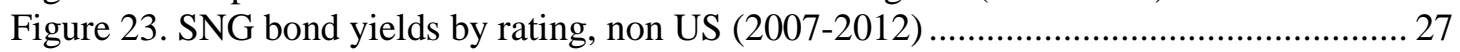

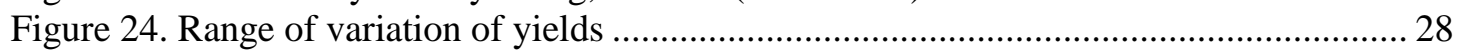

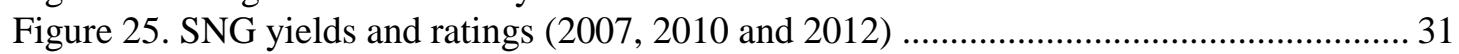

Figure 26. SNG own revenues as a share of GDP (2005-2011) ............................................ 40

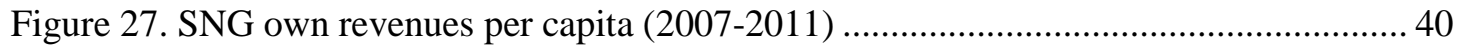

Figure 28. Evolution of current transfers as a share of GDP (2005-2011) ............................. 41

Figure 29. Evolution of current transfers per capita (2007-2011) ......................................... 41

Figure 30. Evolution of capital transfers as a share of GDP (2005-2011) ............................... 42

Figure 31. Evolution of capital transfers per capita (2007-2011) ........................................... 42

\section{Boxes}

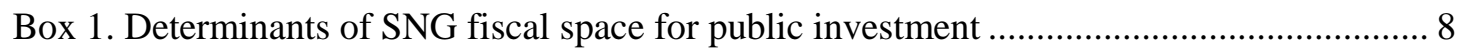

Box 2. SNG direct financing capacity (DFC) indicator......................................................... 14

Box 3. The evolution of DFC and investments in Spanish Autonomous Communities.......... 16

Box 4. The importance of debt to finance local governments' investments in the EU

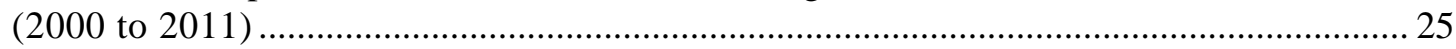

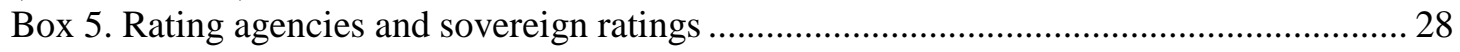

Box 6. Standard \& Poor's methodology for rating SNGs ....................................................... 29

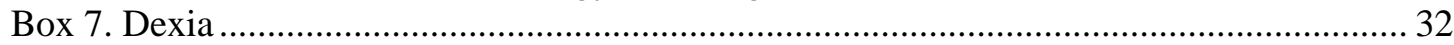

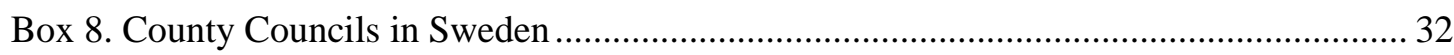

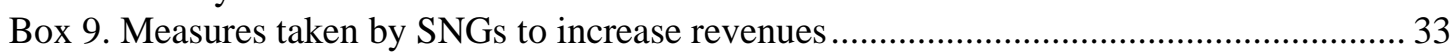

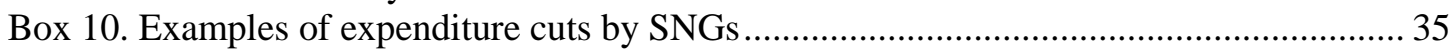

Box 11. Evolution of capital transfers in Italy and Spain ...................................................... 42 


\section{DEFINITIONS}

- Central government (CG) refers to the national, central, or federal government, as it may be defined across countries.

- Regional/state government (RG) refers to the level immediately below the central government in federal countries. This might be defined as "region", "state", province" or "Land", depending on the country.

- Local government or local level (LG), unless otherwise noted, refers to all sub-national governments below the state/regional level in federal countries, and to all sub-national governments in non-federal countries.

- Sub-national government or sub-national level (SNG), unless otherwise stated, refers to all levels of government below the central government level (i.e. includes both regional/state and local governments).

- Sub-national debt refers to the definition of the OECD. This definition is wider than Maastricht debt as it includes insurance technical reserves and other accounts payable, but smaller than total liabilities as shares and equities and financial derivatives (i.e., mostly debt towards providers) are excluded.

- Own revenues are revenues other than transfers (i.e., tax revenues and user fees); autonomous revenues refer to revenues which are modifiable by sub-national governments.

- The average used in this report corresponds to a non-weighted average of OECD countries.

\section{Defining and measuring public investment}

Public investment is generally understood as capital expenditure that finances projects for physical infrastructure (such as roads, government buildings etc.) and soft infrastructure (capital expenditures linked to human capital development, innovation, and research and development) that last beyond the fiscal year. The way public investment is measured across countries varies. In this report, public gross fixed capital formation (GFCF) is used as a proxy for public investment.

Gross Fixed Capital Formation (GFCF) is defined in the National Accounts as: "acquisition less disposals of produced fixed assets, i.e. assets intended for use in the production of other goods and services for a period of more than a year. Acquisition includes both purchases of assets (new or second-hand) and the construction of assets by producers for their own use. The term produced assets signifies that only those assets produced as a result of a production process recognized in the national accounts are included. The national accounts also record transactions in non-produced assets such as land, oil and mineral reserves for example; which are recorded as non-produced assets in the balance sheet accounts and not as GFCF. Acquisition prices of capital goods include transport and installation charges, as well as all specific taxes associated with purchase".

Public investment is difficult to measure. Public GFCF is a narrow definition since it does not cover all public spending that could be considered as investment - it is sometimes difficult to determine the borderline between GFCF and public consumption. For example, acquisition of software with certain kinds of licenses, training of human capital or spending in research and development that 
does not entail any economic benefit for its owner will be classified as consumption, although it could have long-term repercussions. Maintenance operations can be classified either as intermediate consumption or GFCF, according to their magnitude. Public-Private partnerships (PPPs) are not necessarily included in public investment figures either.

\section{Fiscal space for public investment}

Originally raised by emerging countries in the early 2000s, the concept of fiscal space has broadened and been developed in the budgeting literature (Marcel, 2013). According to Heller (2005), "fiscal space can be defined as the availability of budgetary room that allows a government to provide resources for a desired purpose without any prejudice to the sustainability of a government's financial position". This concept has been used extensively in the budgeting literature, with specific focus on sectors such as health or public infrastructure. The term "fiscal space for public investment" will be used in the report to refer to SNGs' capacity to finance investments. 


\section{Introduction}

The global financial crisis and the ensuing consolidation drive have reduced the financial room for manoeuvre of sub-national governments (SNGs). After carrying out stimulus programmes and supporting SNGs during the initial stages of the crisis (2008-2009), most central governments (CGs) switched to financial consolidation strategies. This reversal was particularly difficult for SNGs: while still reeling from the consequences of the crisis, they saw the special measures taken by central governments to support them peter out. In a number of countries, CGs have also been requiring SNGs to participate in the consolidation effort and reduce their deficits and debt (OECD, 2012). In addition, borrowing conditions have deteriorated for the financially weaker SNGs. Banks and financial markets have become increasingly reluctant to lend, as the perceived creditworthiness of sovereign and subnational governments has deteriorated.

As a consequence, SNGs have often been using public investment as an adjustment variable to reduce their budget deficits and preserve their spending on welfare, health or education (Vammalle and Hulbert, 2013). This may have negative long-term consequences for national growth, as SNGs are key regional development actors: they represent $62 \%$ of public investment. In addition, while public investment has traditionally played a counter-cyclical role by compensating falls in private investment, since 2010, both public and private investment levels have been falling (Figure 1).

Figure 1. Variations in private and public GFCF in OECD countries (in \%)

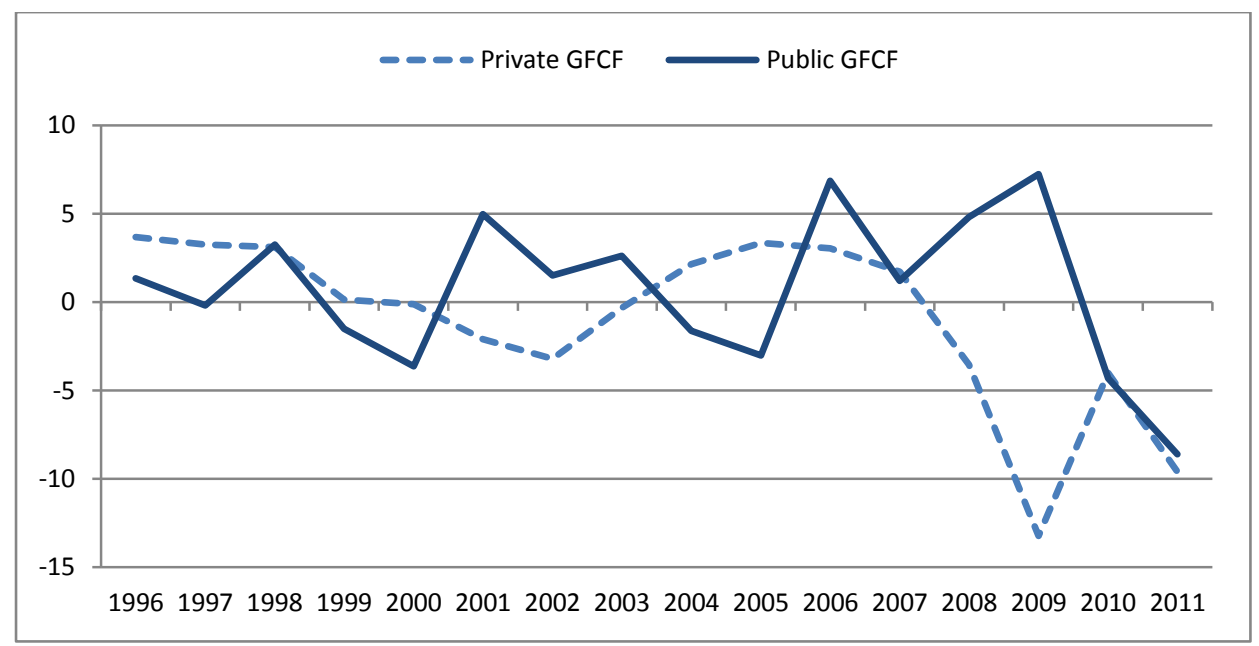

Source: OECD (2013), National Accounts (database), http://dx.doi.org/10.1787/na-data-en (accessed on 20 August 2013).

Public investment is known to be one of the most volatile items in government spending. Early studies (World Bank, 1988) suggested that governments cut capital spending by $35 \%$ on average during fiscal adjustment periods, against $10 \%$ for operating expenditures. These conclusions were confirmed by later studies such as Balassone and Franco (2000), or Blanchard and Giavazzi (2003). Trying to alleviate this specific behaviour of investment spending in times of combined economic turmoil and fiscal adjustment could be a major challenge in order to preserve a country's economic performance and short-term employment.

Public investment in OECD countries is mainly directed to education and economic affairs (which represent on average over 50\% of total investment spending). Economic affairs include 
infrastructure spending, as well as support to economic sectors and firms ${ }^{2}$. Wide cuts in this budget could affect short-term growth and employment, in particular in times of weak economic activity. Regarding education, a prolonged decline in investments could also have a negative impact on long term growth.

The leeway of SNGs to continue investing and implementing policies to enhance long-term growth potential depends on the national framework of fiscal relations across levels of government, the nature and characteristics of SNGs' revenue sources and spending responsibilities, their resilience to the crisis, and their ability to borrow. ${ }^{3}$ This paper develops an indicator of fiscal space for subnational government investment, and analyses the impact of the crisis and ensuing consolidation plans on this indicator.

The fiscal space of a SNG for public investment is determined by its current budget balance, capital transfers received, and the new debt it may issue to finance a project. Fiscal space also depends on how these variables may evolve in the future. The evolution of fiscal space depends on the institutional framework which determines the ability of SNGs to increase their revenues or decrease their spending, ${ }^{4}$ or the financial credibility of an SNG, as well as exogenous factors, such as external shocks on revenues or spending or the ability and willingness of banks and financial markets to finance SNG projects (Box 1).

\section{Box 1. Determinants of SNG fiscal space for public investment}

SNG fiscal space for public investment depends on its ability to increase revenues, adjust spending, and issue debt.

More precisely, on the revenue side, SNG fiscal space depends on:

- The nature of the tax mix (relative reliance on property tax, personal income tax, corporate tax, etc.) and the framework for transfers (formula based, discretionary, etc.)

- The capacity of SNGs to increase their tax rates or bases (tax autonomy)

- The revenue mix of SNGs between own revenues and grants

- The evolution of the regional GDP (as it may influence tax revenues)

- The level of wealth

- Direct effects of national consolidation plans, such as reductions in transfers, or indirect effects such as changes in the rate of shared taxes, or allocation formulae.

On the expenditure side, the fiscal space of SNGs depends on their capacity to redirect spending, which is influenced by:

- The size of SNG expenditure relative to GDP

- The importance of mandatory spending, and the ability of SNGs to adjust spending (spending autonomy)

Borrowing capacity depends on:

2. Categories in Economic Affairs include industry, manufacturing and construction, transport, communication, and R\&D.

3. The ability of sub-central governments for investing also depends on their capacity in terms of strategic design and institutional quality, as studied in the related project "Multi-level governance of public investment: incentives and sub-national capacities".

4. See Vammalle, Hulbert and Ahrend (2014). 


\section{Box 1. Determinants of SNG fiscal space for public investment (cont.)}

- The existing stock of debt

- The evolution of the cost of debt (interest rates and yields)

- Fiscal rules which constrain SNG borrowing

Finally, external factors such as the national and international economic and financial situation also affect SNGs' fiscal space, such as the ability and willingness of banks to lend to SNGs, or private actors' ability and willingness to finance public-private partnerships (PPPs)

This paper presents the recent trends in public investment across OECD countries, and suggests an indicator of direct financing capacity (DFC). This indicator aims at measuring the amount of funds immediately available to finance public investment, without new borrowing or changes in revenues or expenditure structure. It then analyses in depth other determinants of SNG fiscal space for public investment, and their evolution since 2007. It finally examines measures implemented in the framework of national consolidation plans to restore public finances.

\section{SNGs' growing role in financing public investment}

Sub-national governments are key players in the provision of public services and investment. In 2011, they were responsible for $30 \%$ of total public expenditures in OECD countries, while SNG own revenues (i.e., taxes and user fees) accounted for around $20 \%$ of total public revenues (Figure 2).

Figure 2. SNG share in general governments' revenues and expenditures (2011)

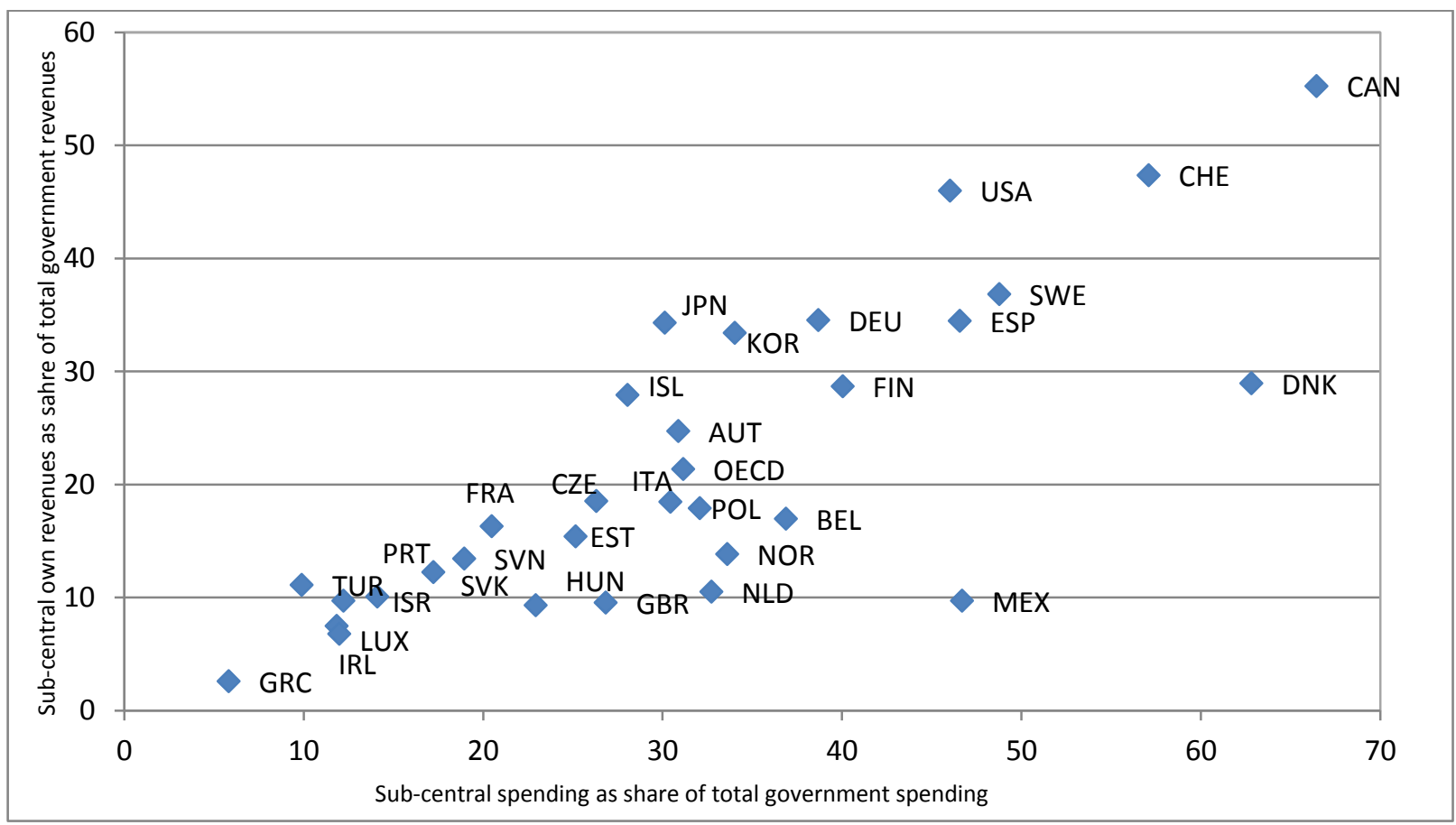

Source: OECD (2013), National Accounts (database), http://dx.doi.org/10.1787/na-data-en (accessed on 20 August 2013). 
More importantly, SNGs are responsible for nearly two-thirds of public investment in OECD countries. However, these averages hide large disparities: this share is larger in very decentralised countries (over $80 \%$ in Canada, Belgium and the United States), and it is lower in historically centralised or small countries (below $40 \%$ on average in Turkey, Greece and Estonia) (Figure 3).

Figure 3. Sub-national share of public investment (2011)

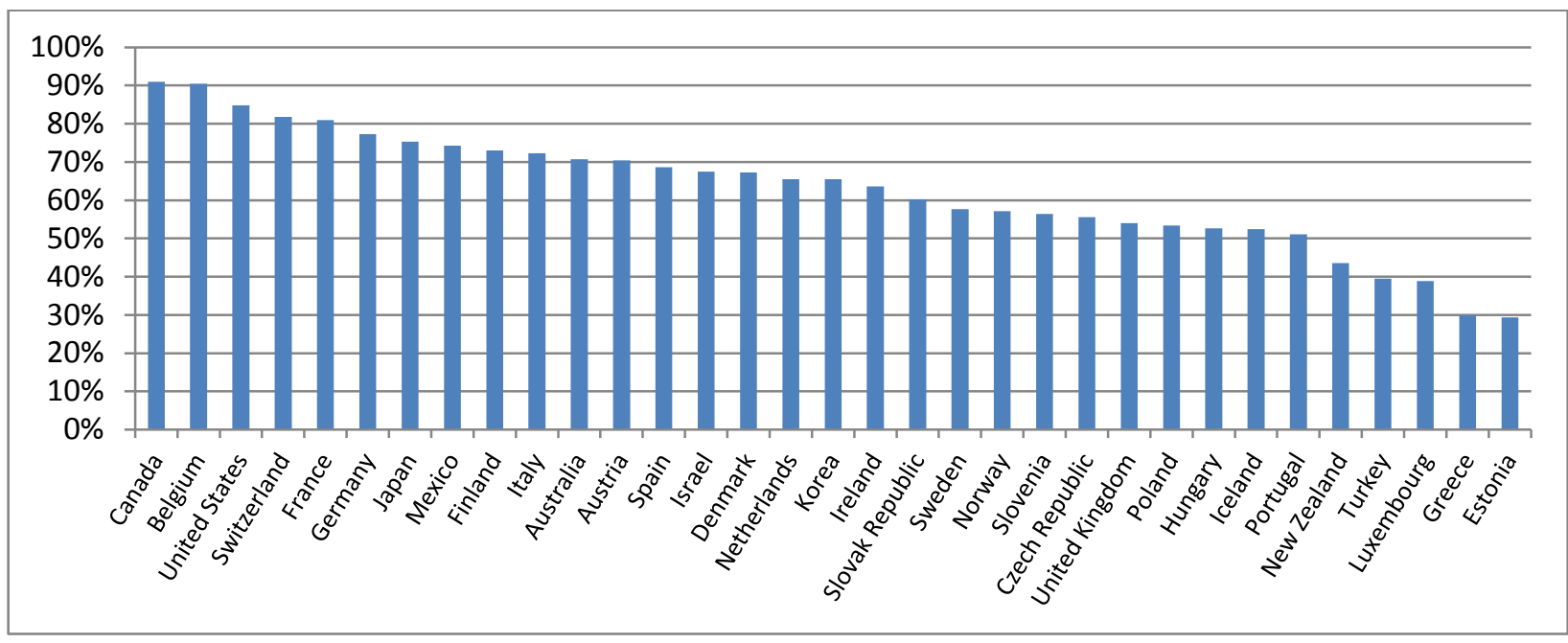

Source: OECD (2013), National Accounts (database), http://dx.doi.org/10.1787/na-data-en (accessed on 20 August 2013).

The high pace of decentralisation over the last decades has increased the share of investments implemented by sub-national governments in historically centralised countries (Figure 4). This evolution has been particularly strong in Eastern Europe, with the notable exception of Estonia.

Figure 4. Evolution of the sub-national share of public investment in selected countries

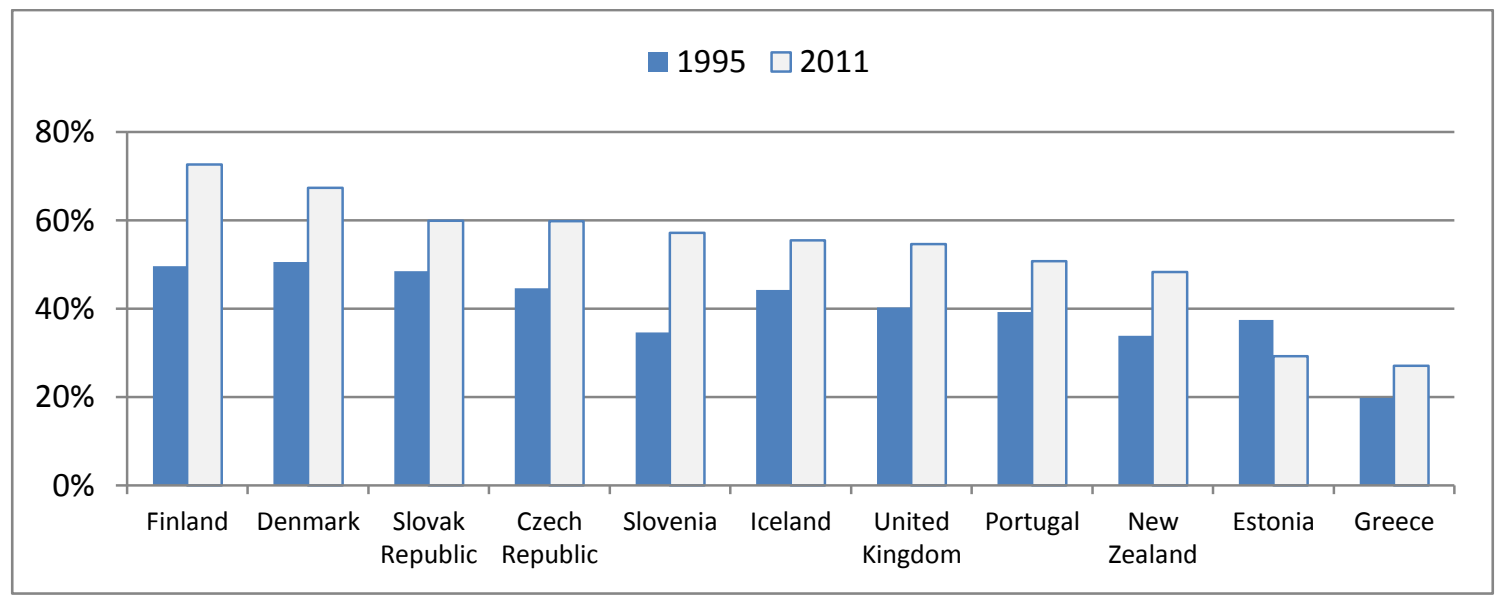

Source: OECD (2013), National Accounts (database), http://dx.doi.org/10.1787/na-data-en (accessed on 20 August 2013).

The global financial crisis affected differently the balance between central and sub-national public investment across countries. Approximately half the countries increased the CG share of investment over 2007-2011 (Figure 5). This evolution of public investment was often linked to stimulus packages (Blöchliger et al., 2010). While this effect would be expected to reverse relatively 
quickly, in countries implementing large consolidation plans, institutional factors influencing public investment may induce long-term changes in the repartition of investments between levels of governments (Vammalle, et al., 2014).

Figure 5. Changes in the share of SNGs in total public investment between 2007 and 2011 (\% points)

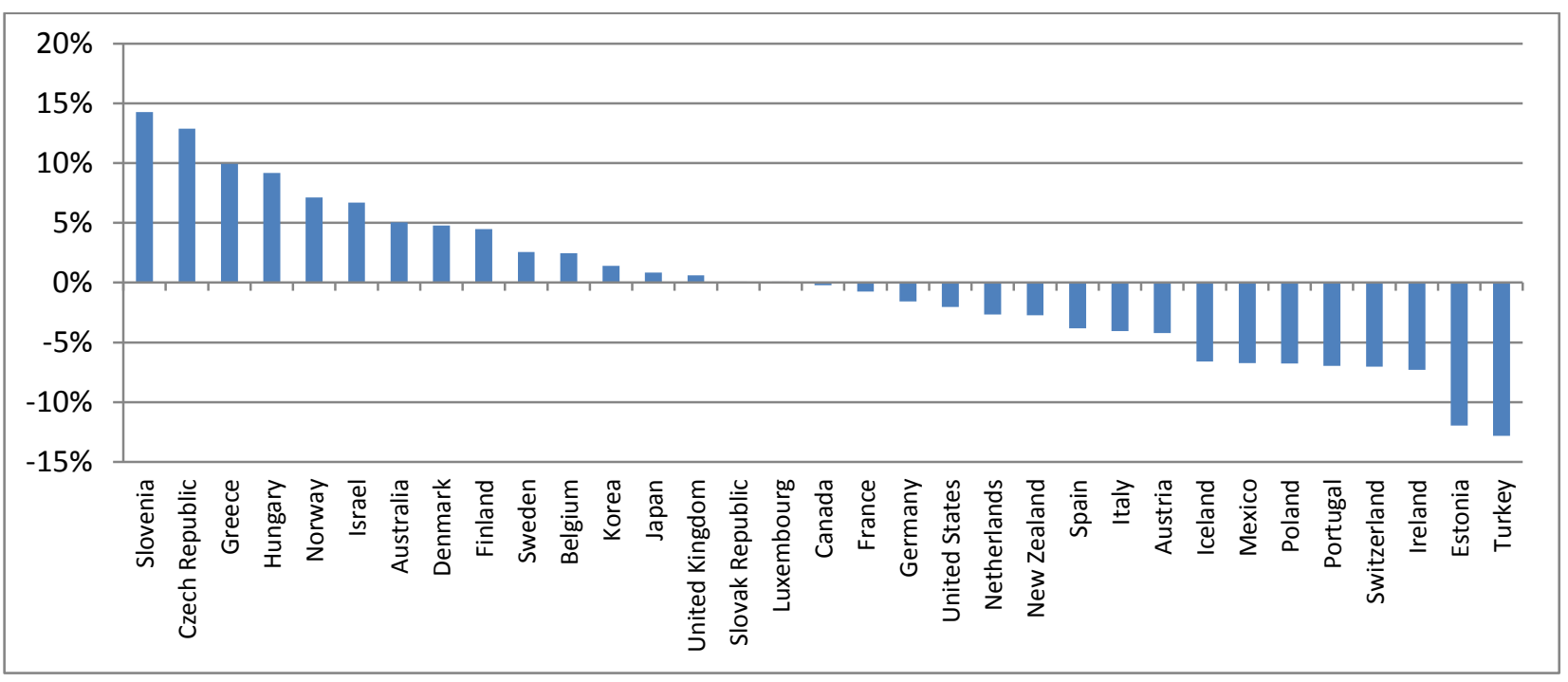

Source: OECD (2013), National Accounts (database), http://dx.doi.org/10.1787/na-data-en (accessed on 20 August 2013).

After supporting public investment to stimulate the economy during the crisis, many OECD countries subsequently cut investment spending to reduce budget deficits. From 2007 to 2009, the implementation of recovery plans in many OECD countries led to higher levels of public investment both at national and sub-national levels. ${ }^{5}$ However, when these plans ended and many countries adopted fiscal austerity packages, public investment declined sharply, especially for SNGs. In 2011, public investment was below its 2007 level in most countries (Figure 6 and 7).

5. This section uses GFCF per capita rather than as a share of GDP, as the growth rate of GDP has been very volatile since 2008, which complicates the interpretations of changes in the ratio of GFCF as a share of GDP. 
Figure 6. Average public investment per capita in OECD countries

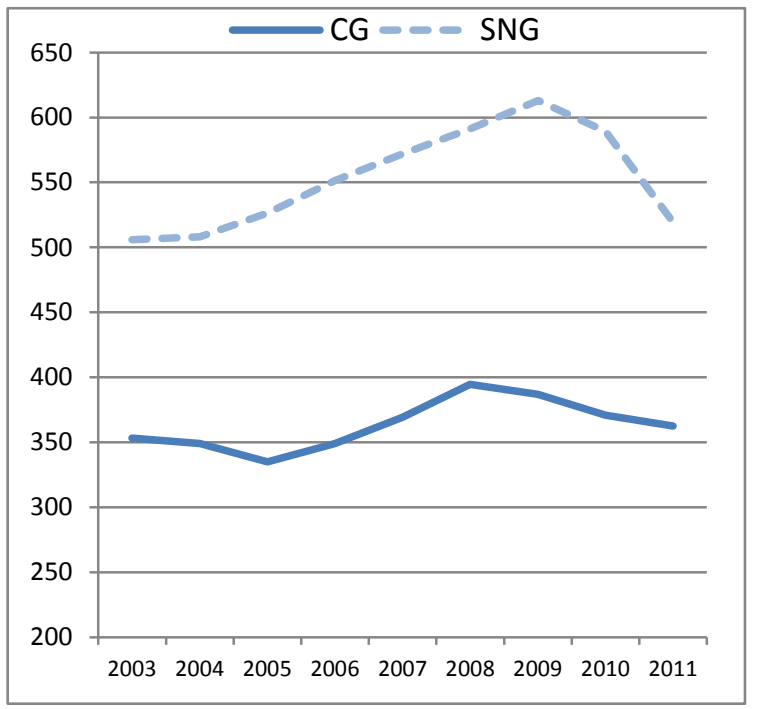

Source: OECD (2013), National Accounts (database), http://dx.doi.org/10.1787/na-data-en (accessed on 20 August 2013).

Public investment is often used as an adjustment variable by SNGs to balance their budgets, as also confirmed by a number of earlier studies (World Bank, 1988, De Haan et al. 1996). Many consolidation programmes even mention explicitly amounts to be saved by reducing public investment (OECD, 2012). Consolidation plans affect public investment not only directly, through reductions in investment expenditures by CGs, but also indirectly. Indirect effects can arise as CGs reduce transfers to SNGs, or through the introduction of deficit targets or expenditure limits, which often lead SNGs to reduce public investment. ${ }^{6}$

General trends in overall public investment hide large disparities between countries. The more severe the economic difficulties faced by a country between 2007 and 2011, the more its overall public investment contracted. The five countries in which the unemployment rate increased by more than 5 percentage points during this period (Estonia, Greece, Iceland, Ireland, and Spain) saw the greatest decline in public investment. On average, CG investment declined by $31 \%$ and SNGs' by $44 \%$ over 2007-2011 (Figure 8).
6. For more details on the involvement of SNGs in fiscal consolidation strategies and information on SNG finances, see Vammalle and Hulbert (2013). 
Figure 8. Changes in per capita public investment in selected countries (2007-2011)

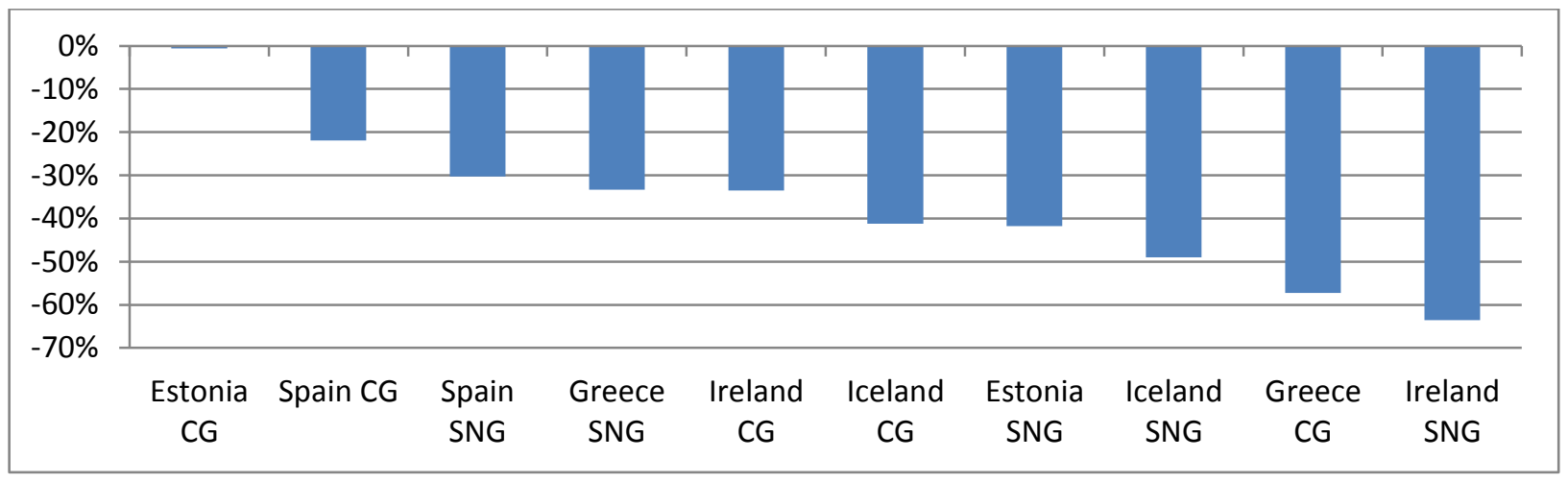

Source: OECD (2013), National Accounts (database), http://dx.doi.org/10.1787/na-data-en (accessed on 20 August 2013).

Between 2007 and 2011, SNG public investment declined more than proportionally compared to other expenditure (thus reducing the share of public investment in total expenditure). Unsurprisingly, for the countries most affected by the financial crises the ratio of public investment to total spending dropped the most (Figure 9). ${ }^{7}$ By contrast, countries which recovered the fastest from the crisis have increased the ratio of SNG public investment to total spending (Mexico, Poland, and Australia, for example).

Figure 9. SNG public investment as a share of expenditures

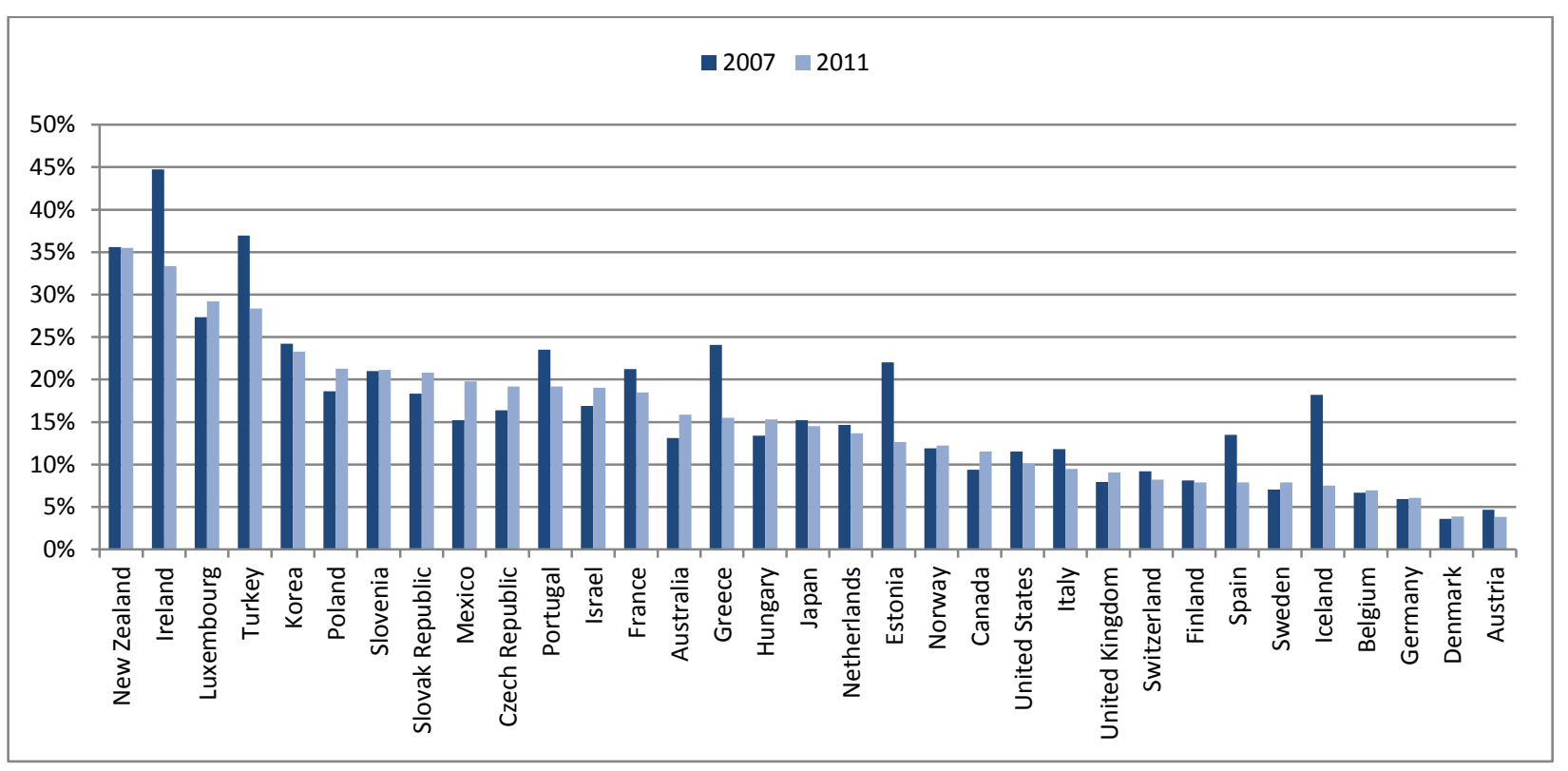

Note: for Canada, Japan, Korea, Mexico and Turkey, data is for 2010 instead of 2011; for Australia and New Zealand, 2009 instead of 2011.

Source: OECD (2013), National Accounts (database), http://dx.doi.org/10.1787/na-data-en (accessed on 20 August 2013).

7. From 2007 to 2011, the share of public investment on SNG expenditure dropped from $16.7 \%$ to $15.4 \%$ on average, but from $18.2 \%$ to $7.2 \%$ in Iceland, from $13.5 \%$ to $7.9 \%$ in Spain, from $24 \%$ to $15.5 \%$ in Greece, and from $44.7 \%$ to $33.4 \%$ in Ireland. 


\section{Direct financial capacity: an indicator of SNG fiscal space for public investment}

\section{Definition of direct financing capacity}

SNG fiscal space for public investment can be influenced by a number of factors, and central and sub-national governments may take institutional measures to increase it. But such increases take time to materialise. This paper therefore proposes a direct financing capacity indicator, which measures the funds readily available for investment without need for reforms or policy changes, and prior to issuing debt (Box 2). Direct financing capacity (DFC) does not necessarily reflect the funds that will actually be used for public investment. Indeed, this surplus can also be saved or used to transfer noninvestment capital to households or public companies (for instance, finance the deficits of local public enterprises). But it is a measure of the available funds that could potentially be used for public investment without changes to other policy settings.

\section{Box 2. SNG direct financing capacity (DFC) indicator}

In order to measure a SNG's fiscal space for public investment, a direct financing capacity indicator is proposed. It is an imperfect proxy for fiscal space, as it lacks an estimation of borrowing capacity; however, it presents interesting information as it measures the funds readily available for public investment. This indicator is defined as:

Direct financing capacity $=$ current surplus + capital transfers received

Where:

Current surplus $=$ current revenues - current expenditures;

Current revenues $=$ own revenues (taxes received + user fees) + current transfers;

Current (operating) expenditures $=$ staff costs + social benefits and other transfers + interests paid + other operating expenditures;

The DFC calculations are non-consolidated between states/regions and localities.

DFC is strongly and positively correlated with SNG public investment spending (Figure 10). Hence it seems that sub-national governments generating fiscal space potentially assignable to public investment do use these resources to invest. This observation is of upmost interest in a public policy perspective; policies that improve fiscal space are likely to have a positive impact on public investment at the SNG level. 
Figure 10. Relation between SNG direct financing capacity and public investment In constant (2005) USD

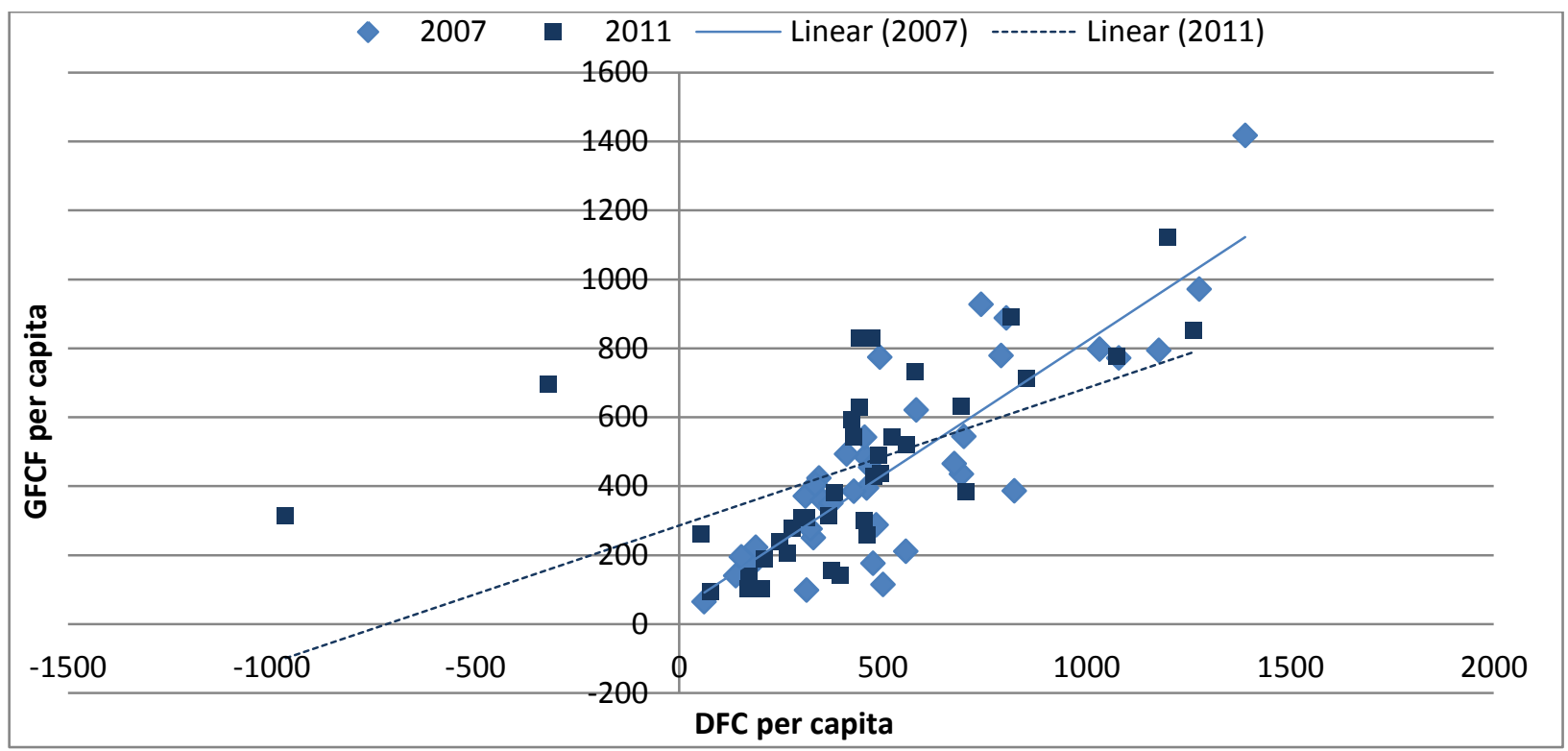

Note: the two outliers are Canadian provinces and Spanish autonomous communities. These two federal entities might stand out because of consolidation issues.

Source: Own calculations based on OECD (2013), National Accounts (database), http://dx.doi.org/10.1787/na-data-en (accessed on 20 August 2013).

\section{Evolution of sub-national government direct financing capacity}

Direct financing capacity of states/regions differs from that of local governments (Figure 11a and $11 b)$. It must be noted that as data is non-consolidated, the level of state/regional DFC's cannot be directly compared to those of local governments DFC's. Indeed, some of the current and capital transfers received by states or regions are transferred to local authorities. While for states/regions, DFC is sometimes negative (meaning that SNGs have to borrow not only to finance public investment, but also to cover operating expenditures), this is never the case at the local level (Figure 11b). Local governments tend to be subject to tighter fiscal rules and mainly rely on past savings and investment revenues to finance public investment. 
Figure 11. Direct financing capacity per capita as a share of SNG revenues

a. States/Regions

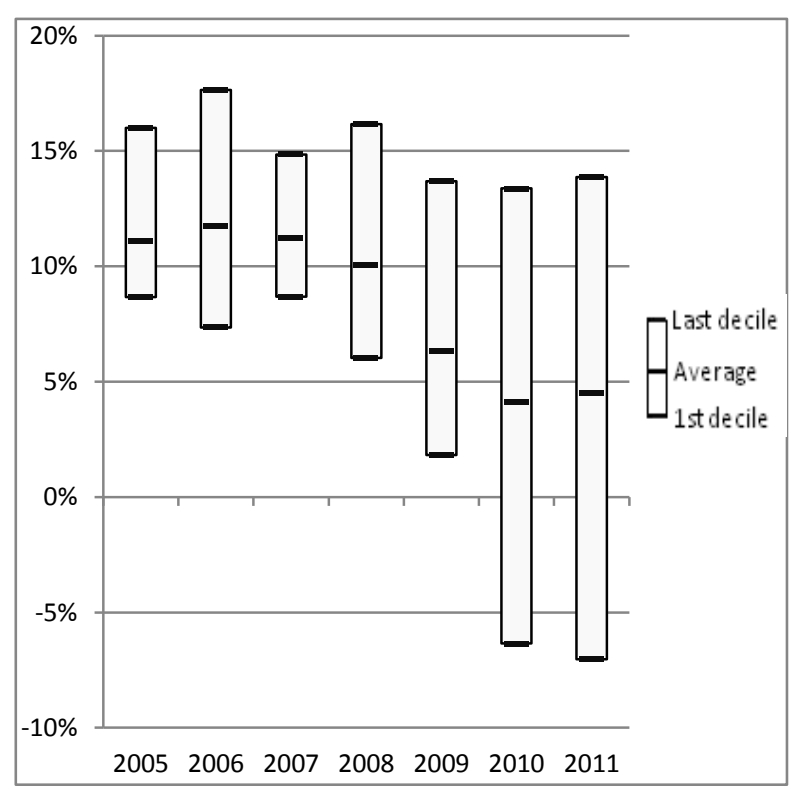

b. Local governments

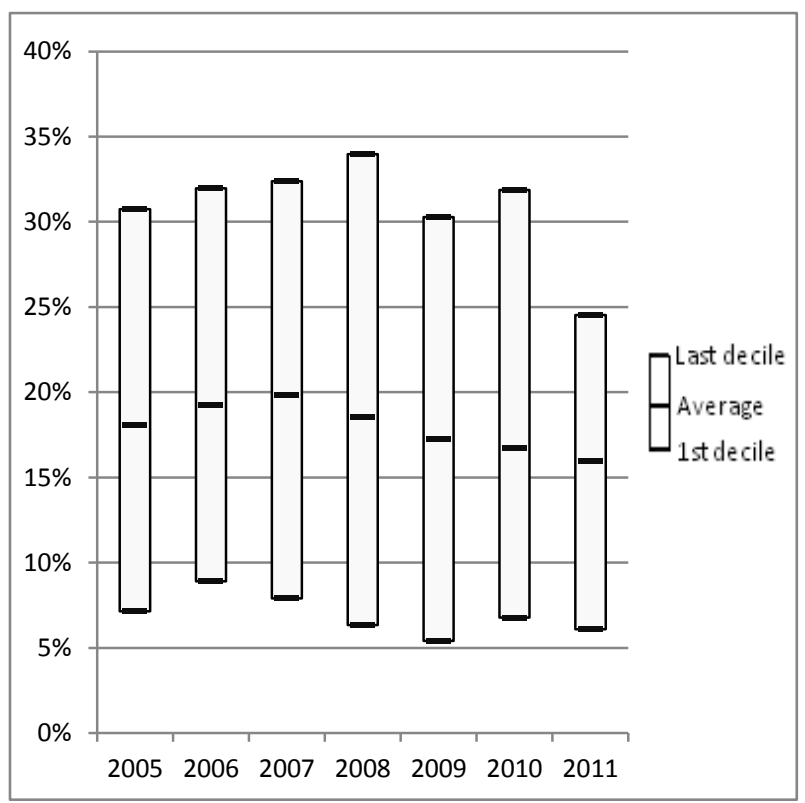

Note: Data for Australia and Chile is missing. Data for Mexico is only available from 2003 to 2009, for Japan from 2005 to 2010 , and for Turkey from 2006 to 2010. Data for 2010 is missing for New Zealand; data for 2011 is missing for Canada, Israel, Korea, New Zealand, Turkey and Switzerland.

Source: Own calculations based on National Accounts OECD (2013), National Accounts (database), http://dx.doi.org/10.1787/nadata-en (accessed on 20 August 2013).

The crisis reduced DFC in states/regions, and increased dispersion. In countries with three tiers of governments, states/regions' DFC as a share of revenues has declined strongly since 2007, droping from $11 \%$ in 2007 to less than 5\% in 2011. In parallel, DFC dispersion among OECD regional/state governments has surged during the crisis (Figure 11a). In some countries, DFC of SNGs increased beteween 2008 and 2009 (Australia, Mexico), while in others, it started declining as early as 2008 (Belgium, Germany, Switzerland). In Spanish autonomous communities, the DFC/Revenues ratio declined from over 15\% in 2007 to less than $-26 \%$ in 2011. A situation where SNGs cannot fully cover their operating expenditures is likely to affect drasticaly public investment (Box 3).

\section{Box 3. The evolution of DFC and investments in Spanish Autonomous Communities ${ }^{8}$}

The DFC ratio has been calculated by using the same methodology as presented above. Even though the real DFC per capita suffered a large decline in all ACs, large disparities among ACs remain. While some regions kept some fiscal space for investment, others were incapable of fully covering their operating expenditures. The DFC ratio was large and negative in 2010 in Castilla-la-Mancha, Communidad Valenciana, Cataluña, Islas Baleares and Murcia. It is therefore hardly surprising that these five ACs were among the regions that invested the least in 2010. In contrast, Asturias and Navarra still generated a DFC above 450 Euros per capita - and were the two regions with the highest investment per capita in 2010.

8. Data is available at the level of Spanish Autonomous Communities (ACs), making comparison between ACs possible. 


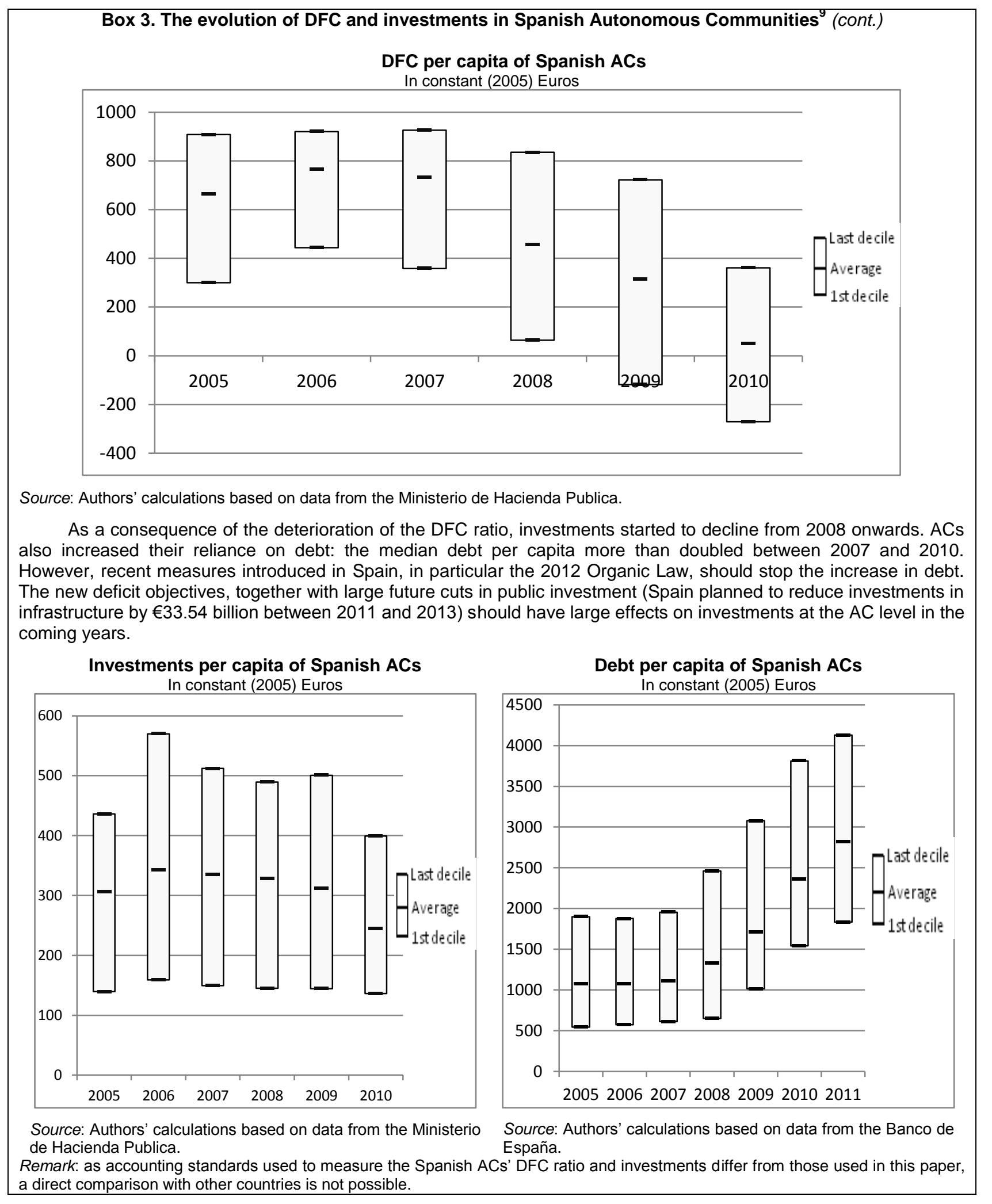

9. Data is available at the level of Spanish Autonomous Communities (ACs), making comparison between ACs possible. 
Local governments' DFC also declined, but less than the states/regions'. Local governments' DFC per capita started declining from 2007 onwards, and stabilised in 2011 - but all through this period remained at or above 2005 levels (Figure 11b). Dispersion among countries has generally been much higher for local governments than for state/regional governments. However, in contrast to states/regions, this dispersion has fallen over the period under consideration.

On a country basis, SNGs' DFC decreased in most countries between 2007 and 2011 (Figures $12 \mathrm{a}$ and 12b). Countries which experienced a deep financial crisis saw a particularly large reduction in SNG's DFC (Iceland, Ireland, Spain). At the other end of the spectrum, SNGs' DFC increased in a few countries which recovered relatively fast (Mexico). When considering DFC as a share of revenues (Figure 12a), it appears that countries known for their high level of public investment (Korea, Ireland, etc.) rank among those with the largest direct financing capacity.

Figure 12. SNG direct financing capacity as a share of revenues

a) 2007 and 2011

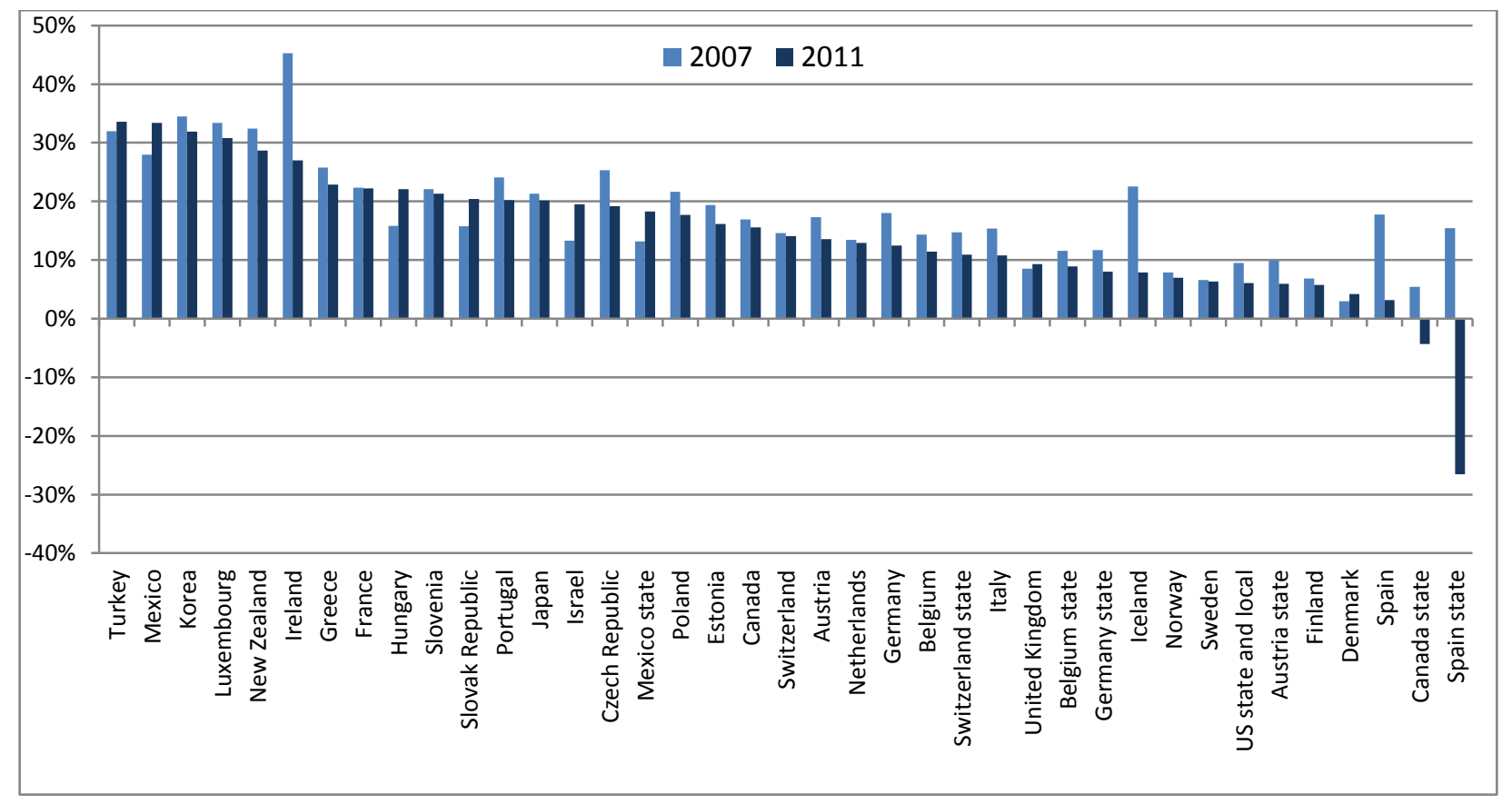


b) Variation between 2007 and 2011 (\% of revenues)

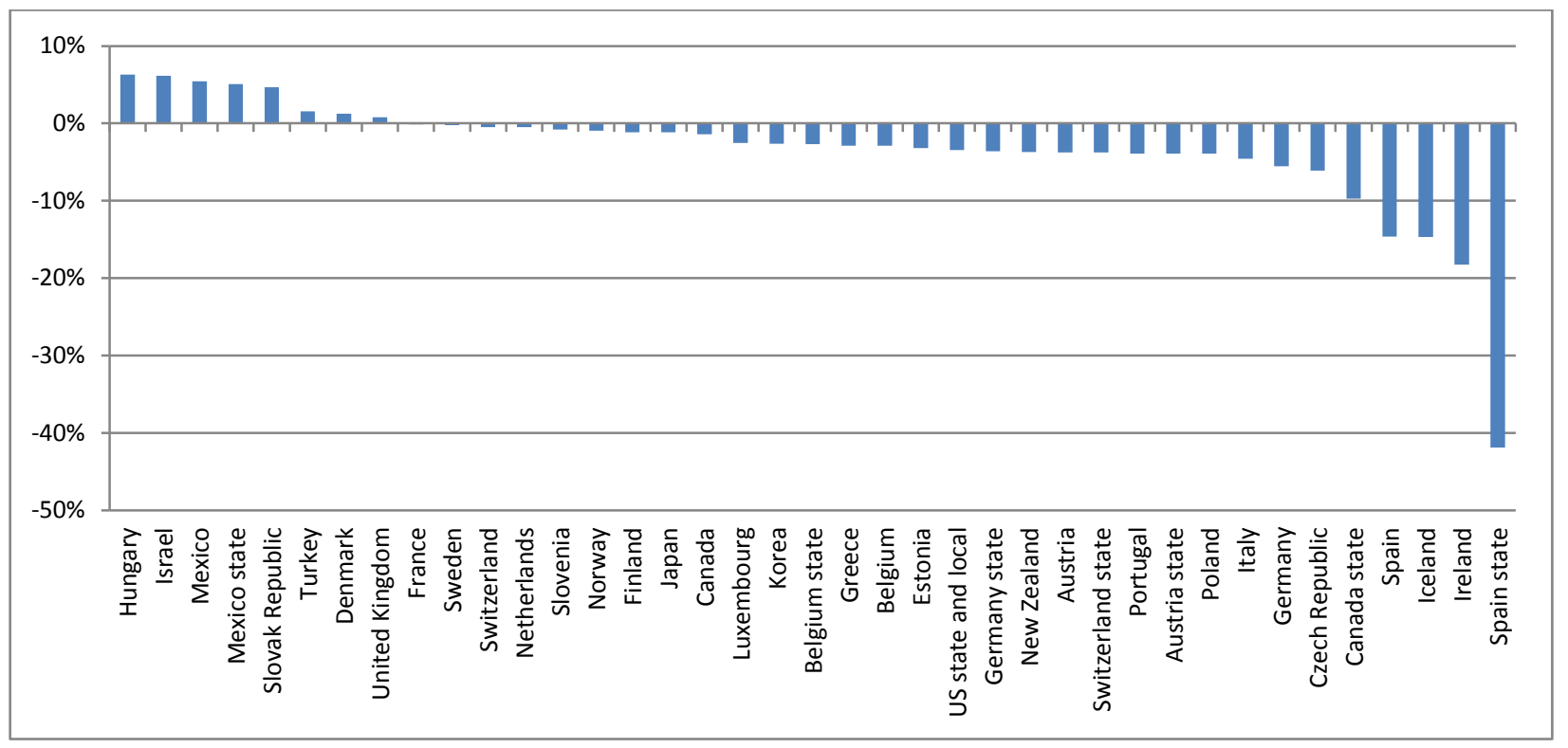

Source: Own calculations based on OECD (2013), National Accounts (database), http://dx.doi.org/10.1787/na-data-en (accessed on 20 August 2013).

\section{Factors affecting sub-national governments' direct financing capacity}

The DFC indicator is an imperfect evaluation of a SNG's fiscal space, as the latter is determined by a number of factors that cannot be synthesised in a single indicator. In particular, the DFC ratio does not include any component relative to indebtedness or to the ability of a given SNG to borrow (interest rates, availability of credit from financial institutions) ${ }^{10}$. Moreover, this ratio is a picture of the fiscal space for public investment in a given year. The main determinants of the fiscal space of SNGs in the medium-term are their capacity to adjust revenue or spending (i.e., taxing autonomy, mandatory spending), and to increase borrowing (access to credit and fiscal rules). ${ }^{11}$ In addition, fiscal space of SNGs is affected by external factors (financial crises, etc.). Other potential determinants, such as economic or political uncertainty, the electoral cycle, agents' expectations or natural catastrophes, are also likely to affect a sub-national governments' fiscal space and are worth mentioning - although they cannot be analysed in detail. This section describes the main determinants of the direct financing capacity ratio, how each of them has evolved since 2007, and how they were affected by national consolidation strategies.

This section shows that the decline in the capacity of SNGs to finance their public investment is mainly due to an upward pressure on operating expenditures, which has not been accompanied by a similar evolution in own revenues, or current and capital transfers received. Own revenues and current transfers actually slightly increased over the 2007-2011 period, while capital transfers decreased on average in OECD countries.

10. Fiscal space has been recently defined for developed countries as "the difference between the current level of public debt and the debt limit implied by the country's historical record of fiscal adjustment" (Ostry et al., 2010).

11. See Vammalle, Hulbert, and Ahrend (2014). 


\subsection{Revenue side}

The size and evolution of SNG revenues and the ability of SNGs to increase them is one of the elements which determine their fiscal space for public investment. This section analyses in depth the revenue components of the DFC indicator, and shows how SNG own revenues, current transfers and capital transfers have evolved since the beginning of the crisis. Institutional factors affecting SNG's capacity to increase their revenues are analysed in Vammalle, Hulbert and Ahrend (2014).

On average, total revenues ${ }^{12}$ were relatively well preserved in OECD countries (Figure 13 and 14), except in countries severely affected by the economic crisis (Iceland, Ireland, Italy and Spain). Local governments' revenues were relatively more preserved than those of states/regions. On average, total revenues per capita (in real terms) went up by $13 \%$ at the local level between 2007 and 2011, while declining by $5 \%$ at the state/regional level.

Own revenues and current transfers appear to have resisted to some extent to the global financial crisis. In most countries, own revenues have grown steadily since 2007 - both at the state and local levels. Current transfers have increased on average between 2007 and 2011, in part reflecting the implementation of stimulus packages in OECD countries.

Capital transfers to localities have shown the largest declines since 2007, although these declines remain moderate. On average, real per capita capital transfers to local authorities declined by 5\% between 2007 and 2011 - this figure is larger in countries severely affected by the economic crisis. However, as a significant share of these transfers is directed towards investment purposes, it is likely that this downward trend had an impact on public investment at the SNG level. Annex 1 presents a more detailed analysis of the sub-categories composing the revenue side of the DFC indicator, i.e. own revenues, current transfers and capital transfers are analysed separately.

12. Total revenues include own revenues (taxes and user fees), current transfers and capital transfers received. 
Figure 13. Evolution of total revenues (\% of GDP)

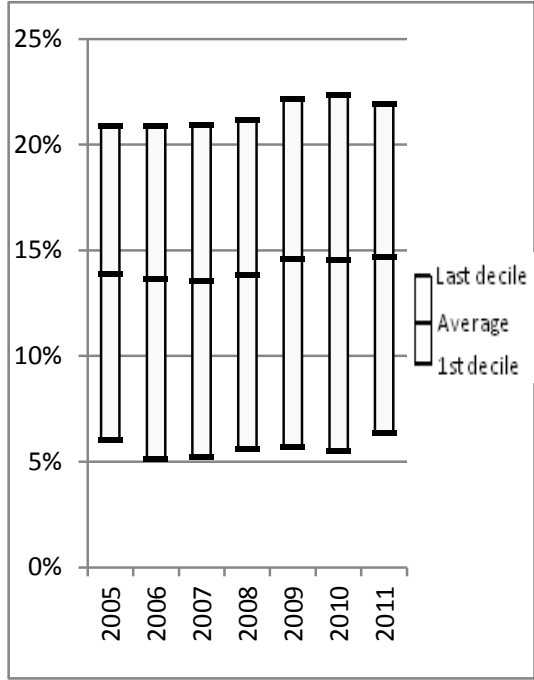

Source: OECD (2013), National Accounts (database), http://dx.doi.org/10.1787/nadata-en (accessed on 23 August 2013). Note: No data for Chile. Data for Canada Korea, New Zealand: 2010 instead of 2011. Turkey from 2006 to 2010.

\subsection{Expenditure side}

Upward pressure on operating expenditures has reduced sub-national governments' funds for investments. Local authorities in particular have seen their operating expenditures rise since the beginning of the global financial crisis, with operating expenditures reaching, on average, $96 \%$ and $84 \%$ of revenues in states/regions and localities respectively in 2011 (compared to $89 \%$ and $80 \%$, respectively, in 2007). This ratio varies importantly between countries; for instance, in Austrian states, Belgium and Canadian provinces, German, Spanish and US states and Denmark local governments, this share was greater than 90\%, while in Korea, Luxembourg, Turkey, Ireland and Mexican localities operating expenditures represented less than $75 \%$ of total revenues in 2011. Of course, countries with the lowest share of operating expenditures are those with the highest share of revenues and GDP allocated to investment (Korea, Ireland and Mexico). In parallel, the average share of total SNG expenditures allocated to current expenditures has increased from $80.5 \%$ to $84 \%$ between 2007 and 2011.
Figure 14. Evolution of total revenues per capita

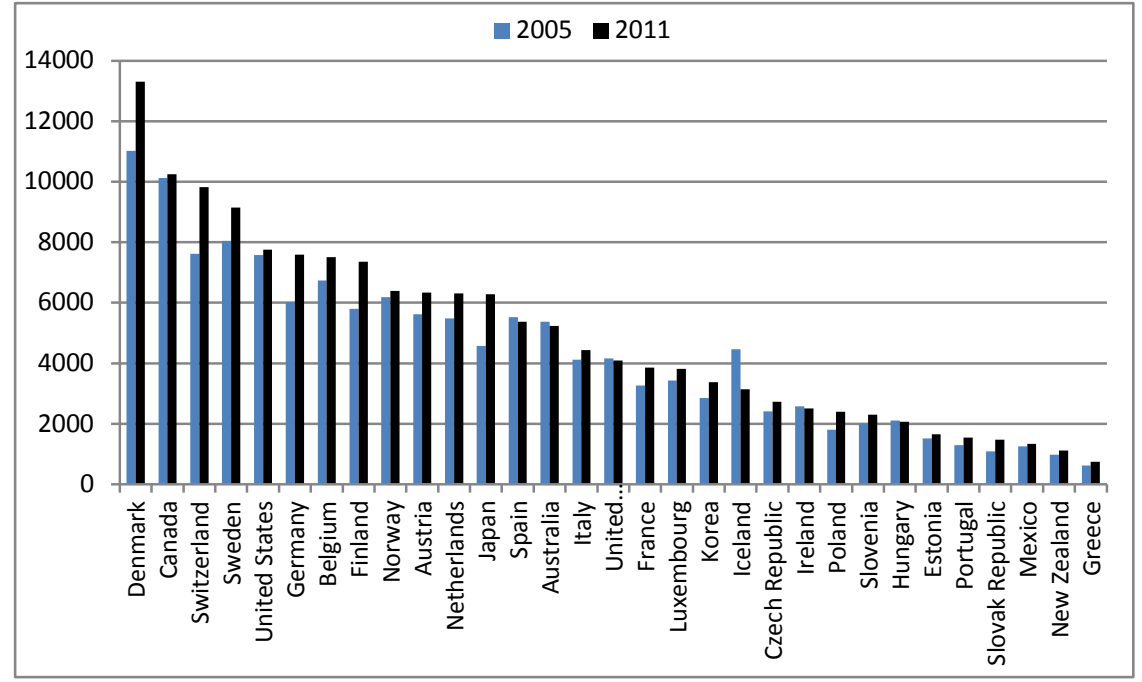

Source: OECD (2013), National Accounts (database), http://dx.doi.org/10.1787/na-data-en (accessed on 23 August 2013).

Note: Data for Australia, Canada, Korea, Luxembourg, Mexico and New Zealand: 2010 instead of 2011. Population for Denmark and Spain: 2010 instead of 2011. In constant (2005) USD 
Figure 15. Evolution of operating expenditures (\% of GDP)

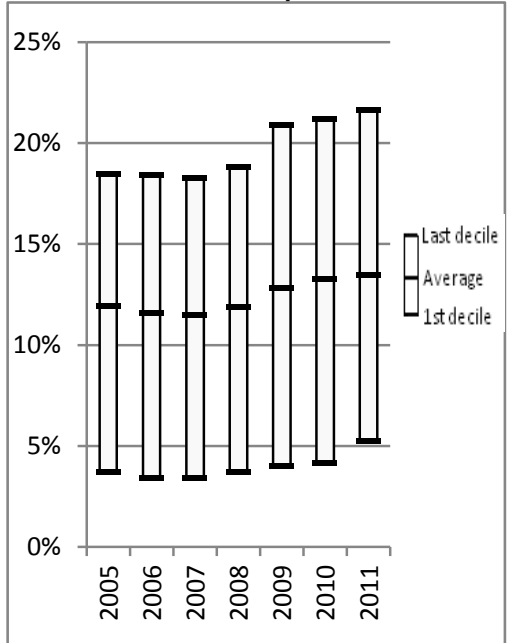

Source: OECD (2013), National

Accounts (database),

http://dx.doi.org/10.1787/na-data-en

(accessed on 23 August 2013).
Figure 16. Evolution of operating expenditures per capita

In constant (2005) USD

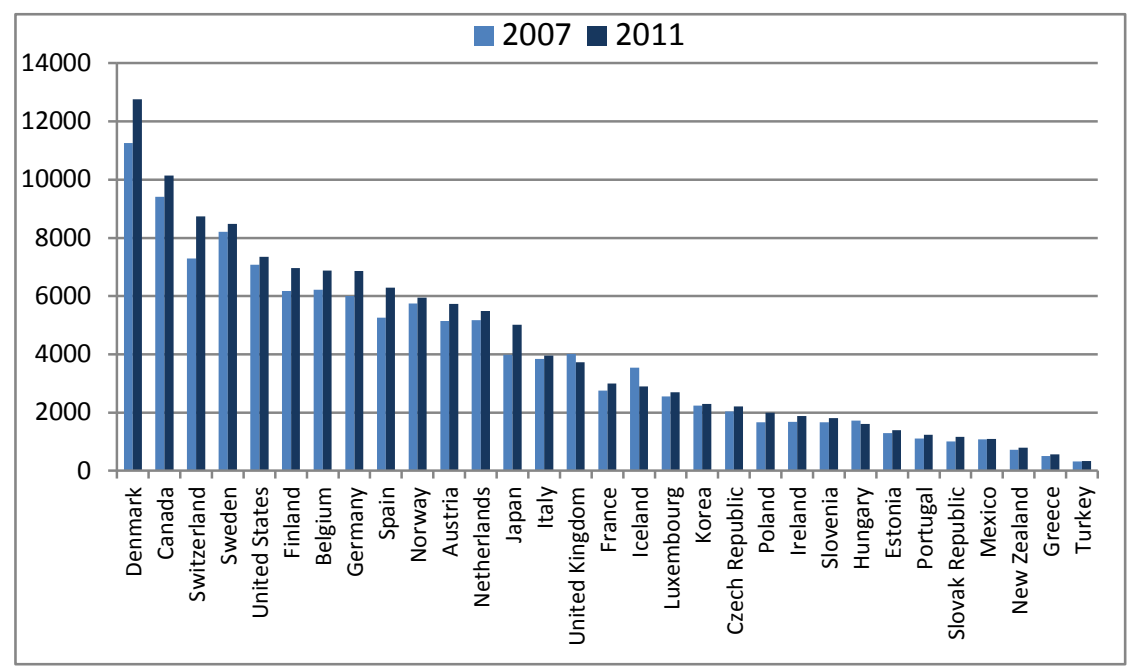

Source: OECD (2013), National Accounts (database), http://dx.doi.org/10.1787/na-dataen (accessed on 23 August 2013).

SNGs' operating expenditures increased both in real terms and as a share of GDP between 2007 and 2008 (Figures 21 and 22). SNG real operating expenditures increased by $12.5 \%$, representing an increase of $465 \$$ USD per capita (measured in 2005\$). Real operating expenditures per capita increased in all countries but Iceland, Hungary and the UK.

Detailed analysis of the evolution of the main categories of current expenditure shows that nearly all the categories included in operating expenditures have risen (in real terms) since the beginning of the crisis (except for interests paid which, on average, declined substantially for local governments). For instance, compensation of employees rose by $10 \%$ over 2007-2011, while intermediate and final consumption increased by $12 \%$ and $13 \%$ respectively. By their size, these categories drove substantially the increase in total current spending.

However, particularly large increases were witnessed in SNG social benefits ${ }^{13}$ and other current transfers $^{14}$ (payable) - which rose on average by more than $20 \%$ and $17.5 \%$, respectively, between 2007 and 2010 (Figures 23 and 24). These large increases had a strong impact on the overall DFC ratio.

13. Social benefits are current transfers, in cash or in kind, granted to households for specific social purposes (health, old age, maternity and family, employment, housing, poverty and social exclusion).

14. Other current transfers payable include specific state insurance premiums, current transfers granted to public administrations, and other current transfers (including specific social transfers - for instance related transfers to public companies - and specific financial support to R\&D, etc.). 
Figure 17. Evolution of SNG social benefits per capita

In constant (2005) USD

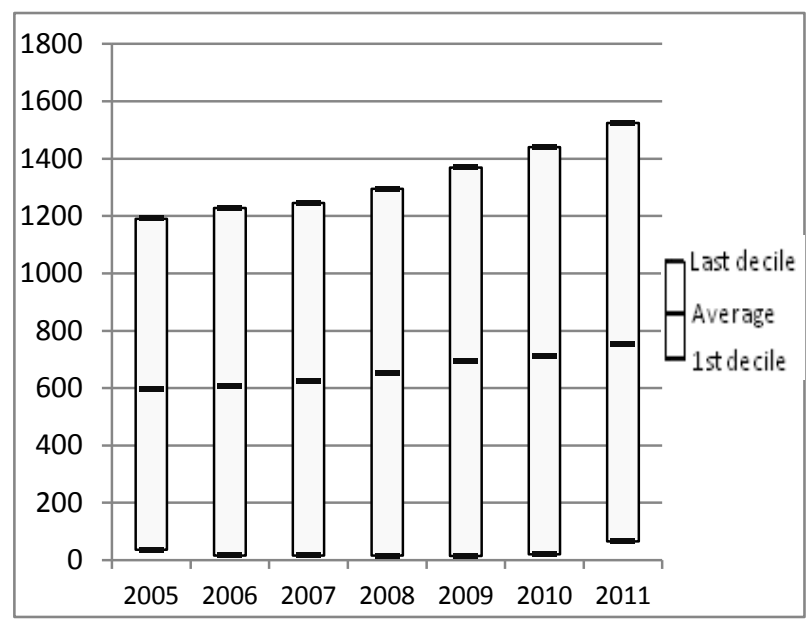

Source: OECD (2013), National Accounts (database), http://dx.doi.org/10.1787/na-data-en (accessed on 23 August 2013).
Figure 18. Evolution of current transfers paid by SNGs per capita

In constant (2005) USD

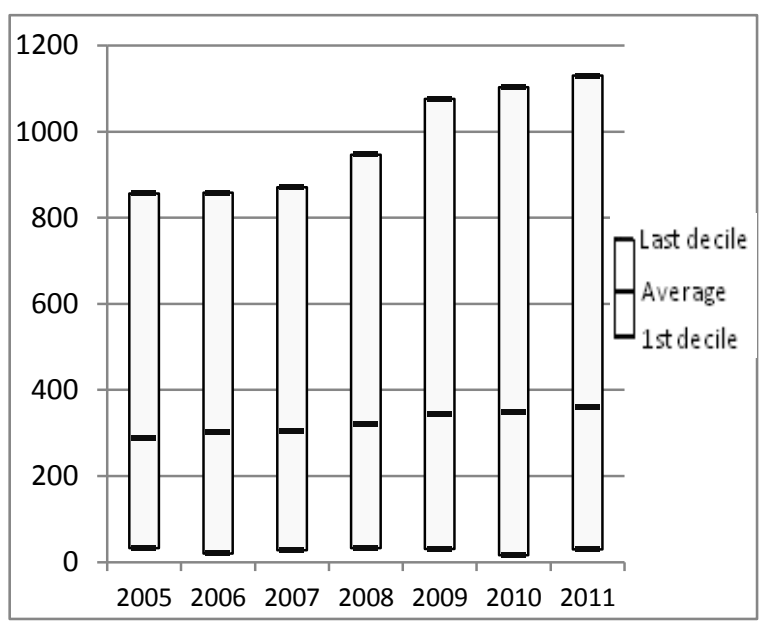

Source: OECD (2013), National Accounts (database), http://dx.doi.org/10.1787/na-data-en (accessed on 23 August 2013).

The increase in social benefits was (at least partly) linked to a deteriorated employment situation and further devolution of social responsibilities to SNGs; the rise in other current transfers was linked in significant measure to higher transfers to private and public companies, and to other levels of government.

In comparison, compensation of employees (the largest category in SNG budgets) grew at a moderate pace, slower than total SNG revenues, since the beginning of the crisis. Therefore, it appears that sub-national support to households and companies since 2007 has participated greatly in the deterioration of SNG public finances, automatically reducing the fiscal space left for sub-national investment.

\subsection{Other factors influencing sub-national direct financing capacity}

Any variable affecting SNG revenues or expenditures is likely to affect SNGs' direct financing capacity, whether directly or indirectly. For example, grants from the central government are often based on economic or socio-demographic indicators (GDP growth, CG's revenues, inflation rate, etc.). Hence, all of these variables may affect SNG revenues and, indirectly, public investment.

SNGs' capacity to increase own revenues depends to a large extent on the income which can be taxed. The simplest indicator of SNGs' revenue base is GDP per capita, and there are wide disparities in GDP per capita and GDP growth among SNGs within countries (Figures 25 and 26). For example, even in countries with positive GDP growth rates, some regions had negative GDP growth rates during the period 2007-09. Reversely, some regions had positive (and sometimes rather high) growth rates in countries with overall negative growth rates (Figure 26). 
Figure 19. Dispersion of GDP per capita within countries (TL2 regions)

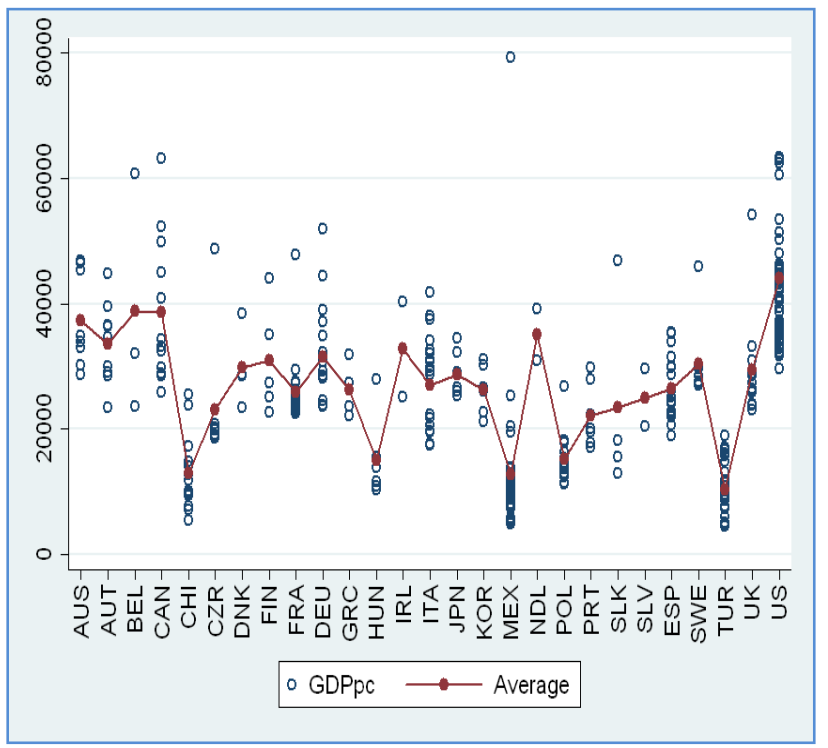

Note: The outlier in Mexico corresponds to the state with the largest oil production in the country.

Source: OECD Regional Statistics (database), http://dx.doi.org/10.1787/region-data-en (accessed on 26 August 2013), Data for 2009, except Canada, Korea, the US: 2010; Greece, Turkey: 2008.
Figure 20. Dispersion of average annual regional GDP growth between 2007 and 2009 (TL2 regions)

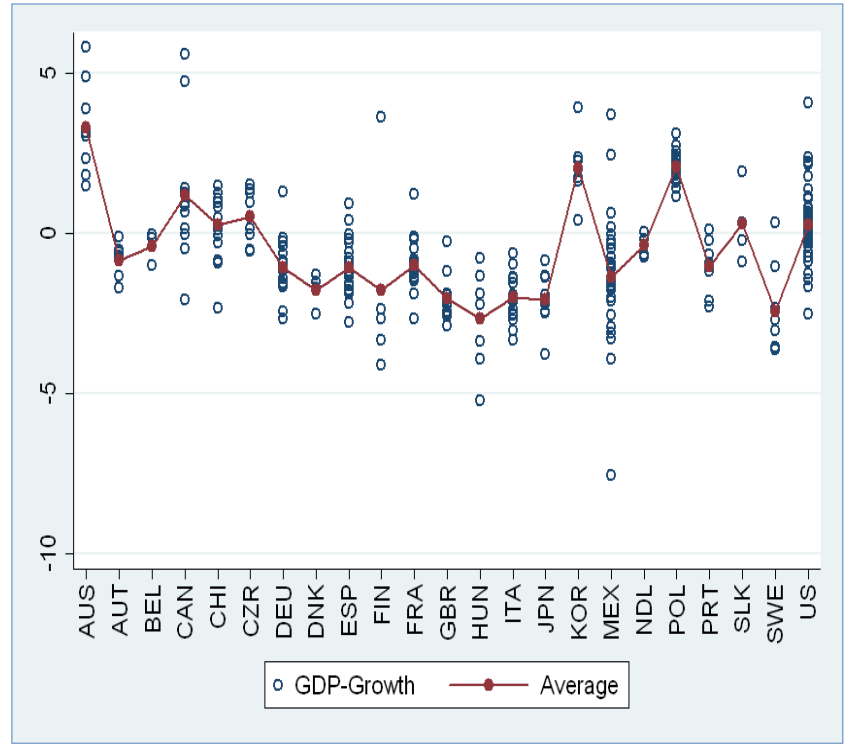

Source: OECD Regional Statistics (database), http://dx.doi.org/10.1787/region-data-en (accessed on 26 August 2013).

\section{Factors influencing SNGs' ability to borrow to finance investment}

Borrowing constitutes and important and growing share of SNG investment financing (Box 5). SNGs' access to borrowing, borrowing costs and borrowing constraints thus affect SNGs' investment capacity.

In many countries, the crisis has triggered a reinforcement of fiscal rules and constraints on SNG borrowing; the evolution of interest rates has reduced SNGs' fiscal space; banks facing difficulties and stricter prudential regulations or capital requirements are less inclined to lend to SNGs; and investors take more and more the possibility of default into account. This has increased difficulties for weaker SNGs to obtain bank loans or access financial markets, while their borrowing costs have increased, thus reducing SNGs' fiscal space for public investment. This section explores the different factors influencing the capacity of SNGs to borrow to finance public investment. 


\section{Box 4. The importance of debt to finance local governments' investments in the EU (2000 to 2011)}

The share of investments financed through debt has nearly doubled since the beginning of the global financial crisis. Over 2000-2011, local investment financing (excluding federal entities) in EU countries consisted mainly of direct financing and capital transfers (investment grants and subsidies). In 2007, just before the crisis, 54\% of investment was self-financed and $40 \%$ was financed by capital transfers. Borrowing only accounted for $6 \%$ (Figure below). With the crisis and the deterioration of gross savings, the rate of investment coverage dropped. In 2011 , only $74 \%$ of local investment was financed by savings (36\%) and capital transfers (38\%). Borrowing accounted for $14 \%$ of investment needs.

\section{Sources of financing for local public investment in the EU (2000-2011)}

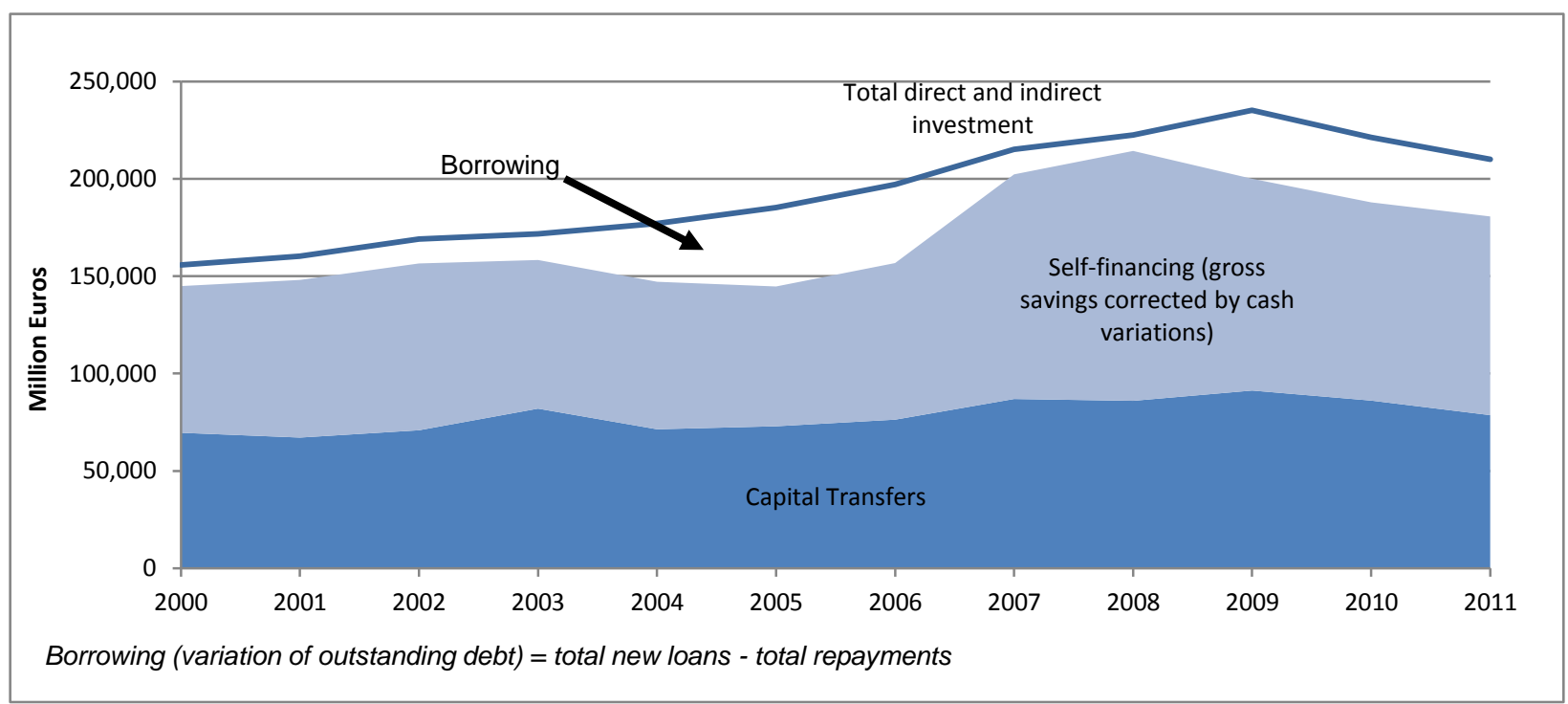

Source: Calculations Dexia Crédit Local/CCRE (I. Chatry) based on data from Eurostat extracted in May 2012.

\section{Existing level of debt}

SNG debt increased form an average of $10.5 \%$ of GDP in 2007 to $13 \%$ in 2012, mainly due to the consequences of the global financial crisis, and the active role many SNGs played in stimulus packages SNG debt thereby accounted for an average of $14 \%$ of total public debt ${ }^{15}$, with the subnational debt share ranging from $1 \%$ in Greece to $53 \%$ in Canada.

15. The share of SNG debt to total public debt has remained rather stable since the mid-1990s, at around $17 \%$ of total public debt. It has slightly decreased since 2007 , as CG debt has been rising faster than SNG's. 
Figure 21. Composition of public debt as a share of GDP (2012)

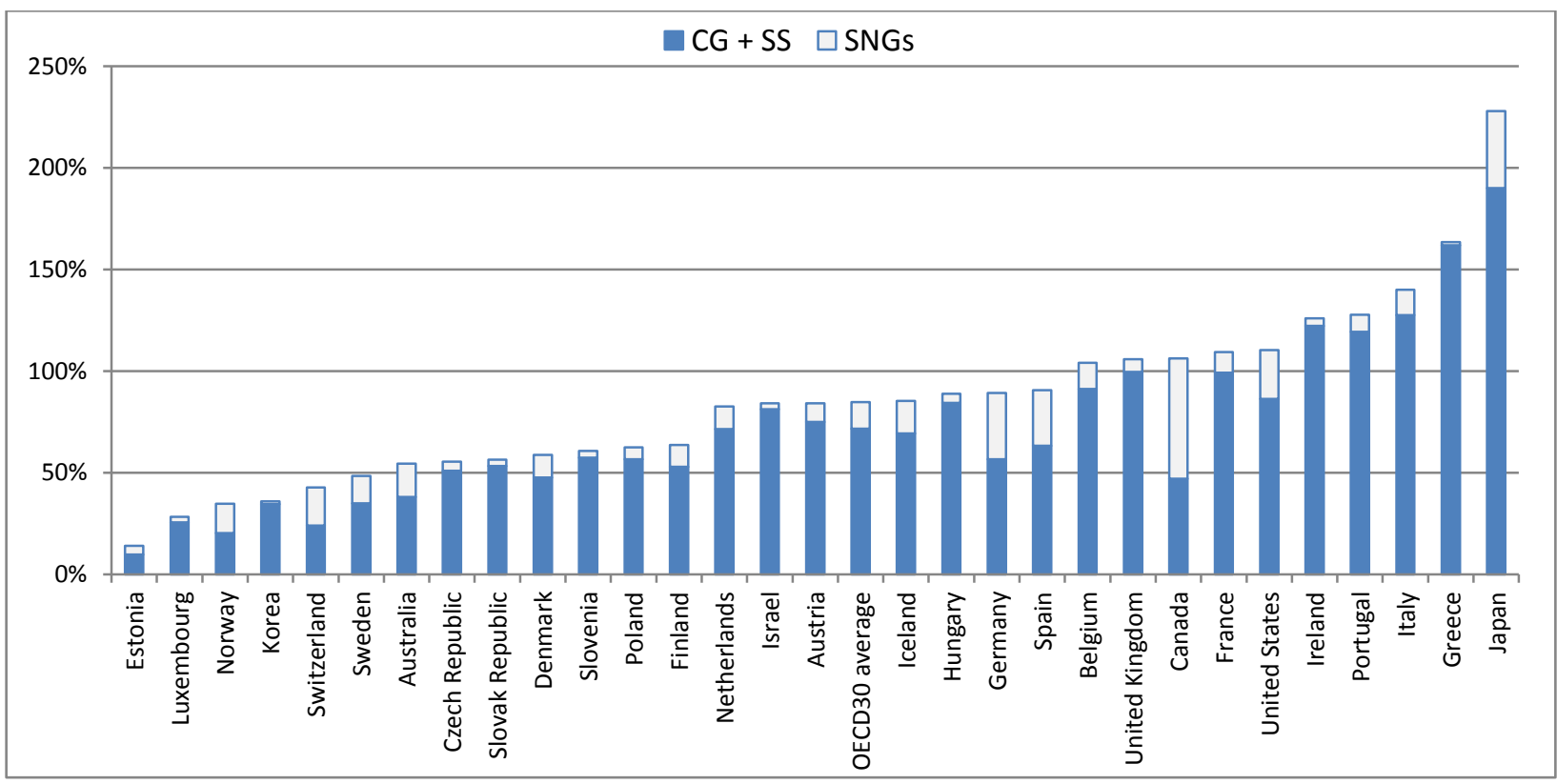

Note: 2010 Switzerland; 2011 Canada, Iceland, Israel, Japan, Korea; no data for Chile, New Zealand, Mexico and Turkey. Data consolidated except for Japan, Korea and the United States.

Source: OECD (2013), National Accounts (database), http://dx.doi.org/10.1787/na-data-en and Eurostat.

However, aggregate numbers hide wide disparities among SNGs within countries. Figure 29 shows the dispersion of SNG debt to revenues ratio in nine OECD countries for which such disaggregated information is available. In most of these countries, some SNGs have levels of debt far above the national average. This implies that at least for certain SNGs, the issue of debt sustainability is more important than suggested by the national averages of SNG data. As contagion may occur if one SNG faces problems to service its debt, it is important to have a full picture of the situation of SNGs, rather than just averages (Box 6).

Figure 22. Dispersion of SNG debt to revenues in TL2 regions (2007-2010)

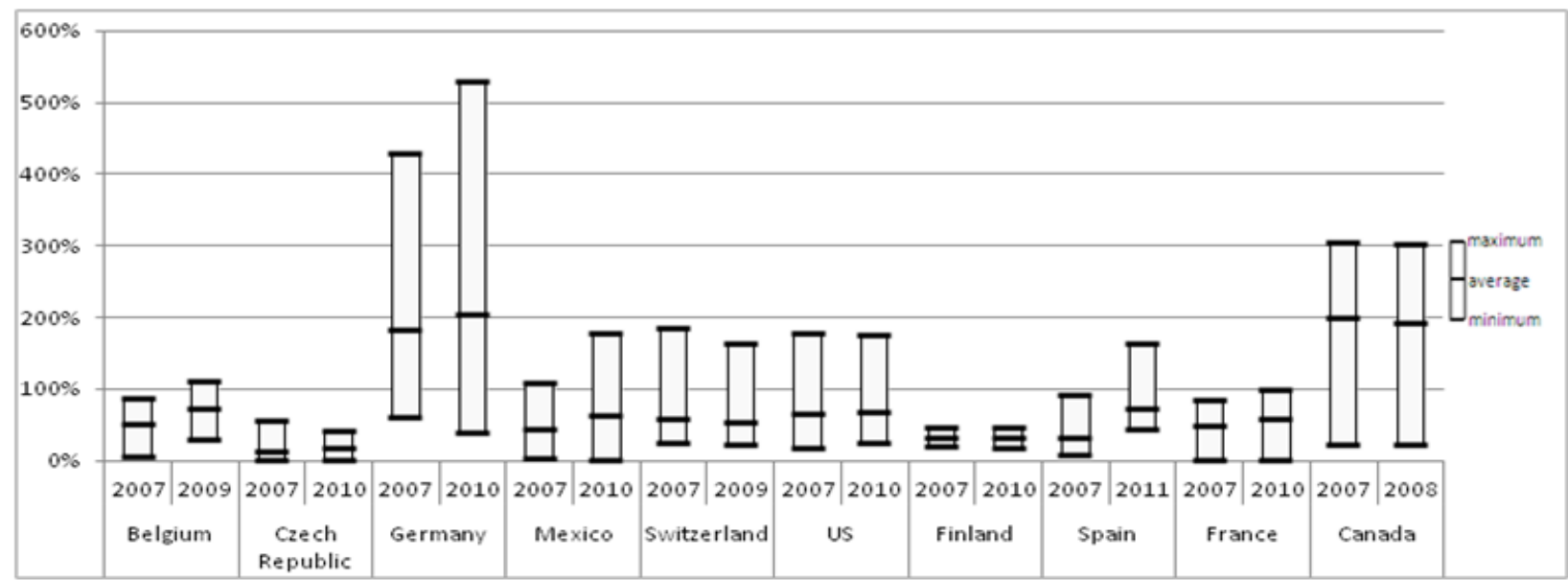

Note: accounting standards used for calculating debt can differ between countries. Therefore this graph is useful in order to get an idea of how disparities evolved over 2007-2010, but countries should not be directly compared.

Source: Own calculations based on OECD National Accounts, OECD questionnaires and publicly available data. 
The existing level of debt of SNGs gives little information about their ability to issue new debt. Indeed, high levels of debt may be the sign of the high level of credibility and revenue raising capacity of the borrower. On the contrary, low levels of debt may have different explanations, such as institutional constraints on borrowing, sound public finances, or on the contrary, it may reflect investors mistrust and unwillingness to lend to this borrower.

\section{Perception by financial markets}

Financial markets increasingly differentiate between low and high-risk SNGs. During the 200708 global financial crisis of (and in particular, in the wake of the fall of Lehman Brothers in October 2008), credit flows from financial markets to SNGs perceived as riskier borrowers were temporarily disrupted (Box 7). In contrast, top rated SNGs benefited from a flight to quality and continued to tap international bond markets without major difficulties (Vammalle et al., 2011). ${ }^{16}$ Since 2011, this trend has been reinforced in non-US countries: yields of high quality (i.e. high-rated) bonds were lower in 2012 than in 2007, while yields of less creditworthy SNGs have reached record heights (Figure 30). The fall in the yield of A-rated bonds in January 2012 is due to the downgrades of Andalusia, Baleares, Catalunia and Madrid from A to the BBB. Financial markets had been pricing the yield of these securities above those that remained in the A category since the beginning of 2009.

Figure 23. SNG bond yields by rating, non US (2007-2012)

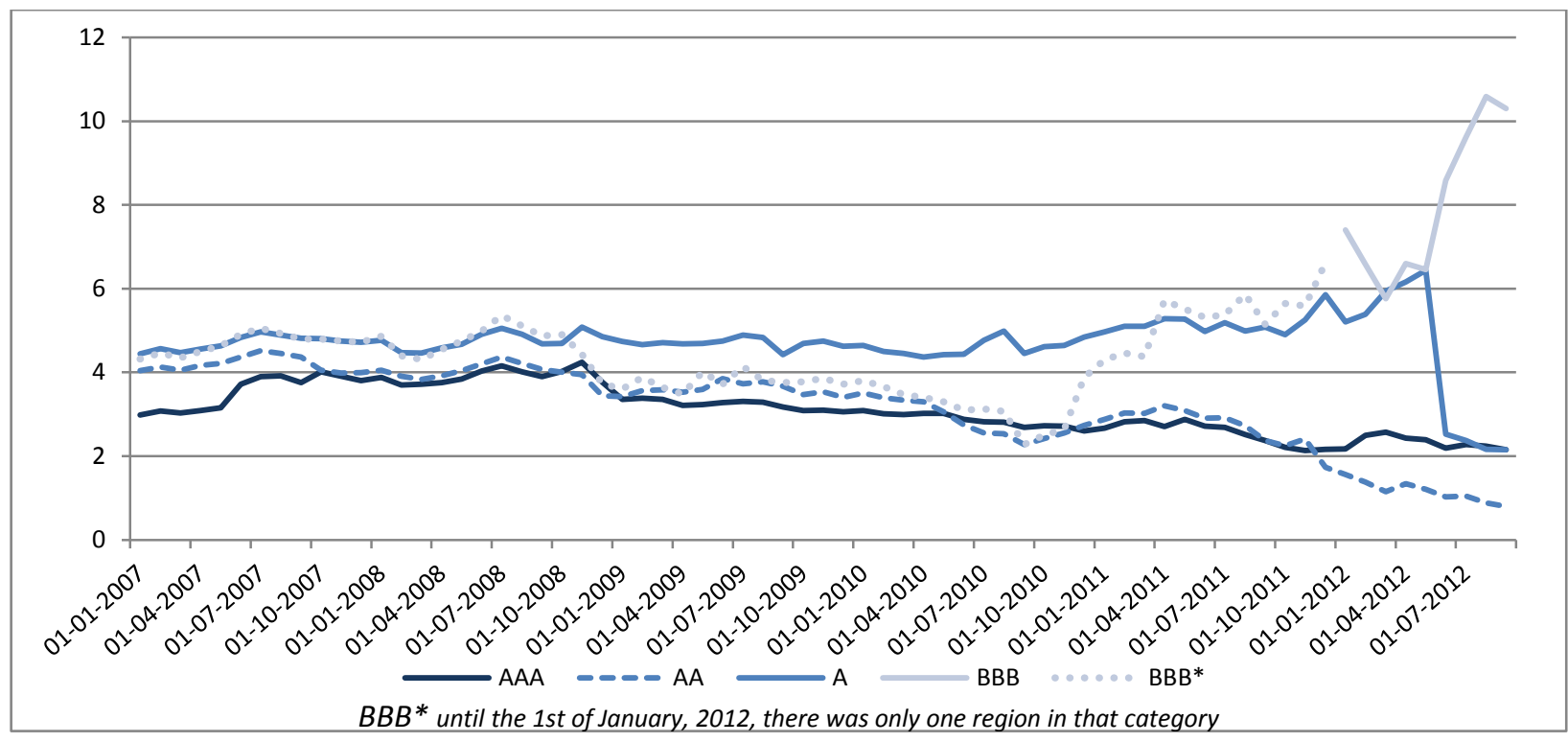

Source: Own calculations based on Datastream.

16. AA-rated bonds quote below AAA rated one at times, showing that the financial markets do not always follow rating agencies' opinion. 


\section{Box 5. Rating agencies and sovereign ratings}

A credit-rating agency is a private firm that assigns credit ratings to issuers of certain types of debt obligations, as well as the debt instruments themselves. In most cases, the rated issuers are national governments, sub-central governments, private companies or structured products.

A credit rating measures the issuer's credit-worthiness (i.e. its capacity to pay back its debts). Credit ratings affect the interest rate at which the issuer can issue bonds (i.e. borrow on the financial market). The higher the rating, the lower the return that investors will demand to hold the bond, as the probability of default (i.e. the risk of holding the bond) is lower.

There are three main rating agencies: Moody's, Fitch, and Standard and Poor's. They use similar types of ratings: the highest rating is "AAA" (assigned by Fitch and Standard and Poor's to issuers with the lowest credit risk), ahead of the "AA", "A", "BBB", "BB", "B", "CCC", "CC" and "D" categories. Moody's corresponding rating scale is as follows: "Aaa", "Aa", "A", "Baa", "Ba", "B", "Caa", "Ca" and "C".

Bonds are classified in different credit-risk categories according to their ratings. Using S\&P terminology, bonds rated AAA and AA are considered high credit-quality or "investment grade". Those rated AA and BBB are called medium credit-quality, and are still considered as investment grade. BBB, B, CCC, CC and C rated bonds are low credit-quality (non-investment grade), also called "junk bonds". Bonds in default or non-payment of principal and/or interest are classified as $D$ bonds.

The value of credit ratings was widely questioned as a result of the 2007-09 financial crisis because the rating agencies had failed to correctly assess the risk of the subprime instruments. The importance given to ratings in international financial regulations has also been criticized. Ratings are used to assess the risk of an investment portfolio. Therefore, when a rating falls below a certain threshold (known as "investment grade"), most pension funds and banks feel compelled to sell the security, contributing to the collapse of its price.

Source: Vammalle et al., 2011.

The spreads between maximum and minimum SNG bond yields increased after the Lehman collapse in October 2008. After an initial increase from less than 200 basis points in 2007 to about 300 basis points, spreads remained relatively stable until the end of 2011. At that time, the growing doubts about the capacity of Spanish and Italian SNGs to consolidate and their frequent downgrades by rating agencies ${ }^{17}$ resulted in surging spreads. In 2012, spreads reached 1000 basis points in Spain (Figure 31). This rise in spreads reflects that investors increasingly priced in the possibility of defaults by some SNGs.

Figure 24. Range of variation of yields (in \% points)

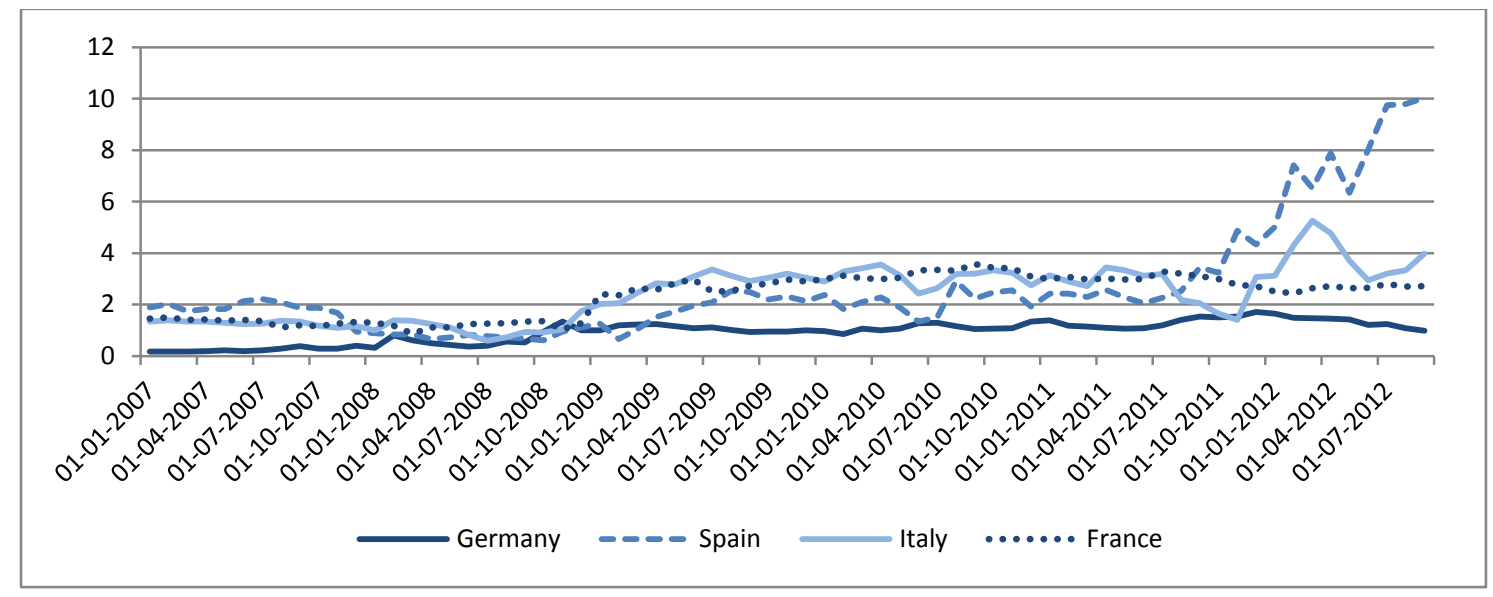

Source: Own calculations based on Datastream.

17. See Annex. 


\section{SNG credit ratings}

For accessing financial markets, SNGs must get a rating from a rating agency. Ratings represent the opinion of the rating agency on the creditworthiness of a specific borrower. Rating agencies assign credit ratings to SNGs based on their qualitative and quantitative analysis of a range of financial, economic, managerial and institutional factors, aiming to assess the ability and the willingness of the SNG to meet its financial obligations (Box 6). These are roughly the same criteria used by banks to grant loans to SNGs.

\section{Box 6. Standard \& Poor's methodology for rating SNGs}

Standard \& Poor takes into account eight major criteria for assigning a rating to a local or regional government. For each of these, it looks at a number of factors and indicators.

\section{The institutional framework}

- Its predictability (the frequency and extent of reforms affecting the intergovernmental system, ability of SNGs to oppose reforms affecting their financial balance)

- Revenue and expenditure balance (overall adequacy of revenues to cover expenditure mandates, existence of fiscal rules and expenditure limits)

- Transparency and accountability (transparency and institutionalization of the budgetary process, disclosure and financial reporting)

- System support (bailout expectations)

\section{The economy}

- Wealth and income levels (GDP per capita can give a reliable indication of the potential tax base)

- Diversification of the economic structure (important to assess the potential volatility of the tax base and its resiliency to stress),

- Demographic profile (as it affects both the revenue structure and the types of services the SNG provides to its population)

- Growth prospects (based on recent and projected trends in output, employment, productivity and investments)

\section{Financial management}

- Transparency and disclosure (clarity and comprehensiveness of financial disclosures as well as the timeliness and frequency of their publication)

- Budgeting (comprehensiveness of the budgeting methods and consistency with the long-term financial strategy)

- Long-term capital and financial planning (credible and well-documented long-term financial plan that supports financial discipline and stability)

- Revenue and expenditure management (whether planning and monitoring during the year are consistent with fiscal targets)

- Debt management (use of short- and long-term debt, risks arising from interest rates and currency movements, etc.)

- Reserve and liquidity management (investment and liquidity policies, appetite for risk, ability to forecast cash flows, etc.)

- Management of government-related entities (level of clarity around their purpose, financial performance and operational effectiveness)

- Political and managerial strength (commitment and ability to implement fiscal discipline)

- External risk management (ability to identify, measure and plan responses to key external risks)

\section{Budgetary flexibility}

- Its ability to raise taxes, fees or tariffs

- The political willingness and economic limits that could curb use of this flexibility

- Potential revenues from asset sales

- Willingness and ability to cut expenditures 


\section{Box 6. Standard \& Poor's methodology for rating SNGs (cont.)}

\section{Budgetary performance ${ }^{18}$}

- Operating balance as a percentage of adjusted operating revenues

- Balance after capital accounts as a percentage of total adjusted revenues

6. Liquidity

- Importance of the national framework

- Internal cash flow generation capability

- External liquidity deriving from committed bank facilities and market access

- Use of stress analysis in cases where SNGs encounter substantial market turbulence

\section{Debt burden}

- A forward-looking assessment of debt stocks and interest burden

- Potential volatility on the cost of debt from exposure to market risks

- An assessment of other long-term liabilities, mostly unfunded pension liabilities

8. Contingent liabilities

- Contingent liabilities from a large non-financial company (implicit or explicit guarantee to provide support to public or private companies)

- Financial companies (when SNGs own, control or guarantee a financial institution)

- Public-private partnerships

\section{Standard \& Poor's methodology for rating SNGs}

- Securitisations (when it is used by SNGs to raise debt off-balance sheet, S\&P consolidates it in the SNG debt)

- A multitude of small companies (which may make it difficult to obtain information on all of them)

- Litigations (linked for instance to expropriations or environmental considerations)

- Other unfunded postemployment benefits (including items such as vested sick leave and unused vacation time)

- Other contingent risks (deriving from workers' compensation, insurance plans, guarantees to households, etc.)

Source: Standard \& Poor's (2010).

The average rating of bonds decreased during the period, with more bonds getting low ratings in 2012 than in 2007, and differentiation of borrowers increased (Figure 32). Plotting SNG yields against their respective ratings unsurprisingly shows a correlation between the yields and the ratings (better rated securities enjoying lower yields), but this correlation has evolved from 2007 to 2012 (Figure 32): yields of low rated securities increased, while the yields of the top rated ones decreased (Figure 32).

18. As accounting practices and standards vary across countries, S\&P makes a series of adjustments to SNGs' reported financial indicators to obtain comparable financial data across jurisdictions. 
Figure 25. SNG yields and ratings $(2007,2010$ and 2012)

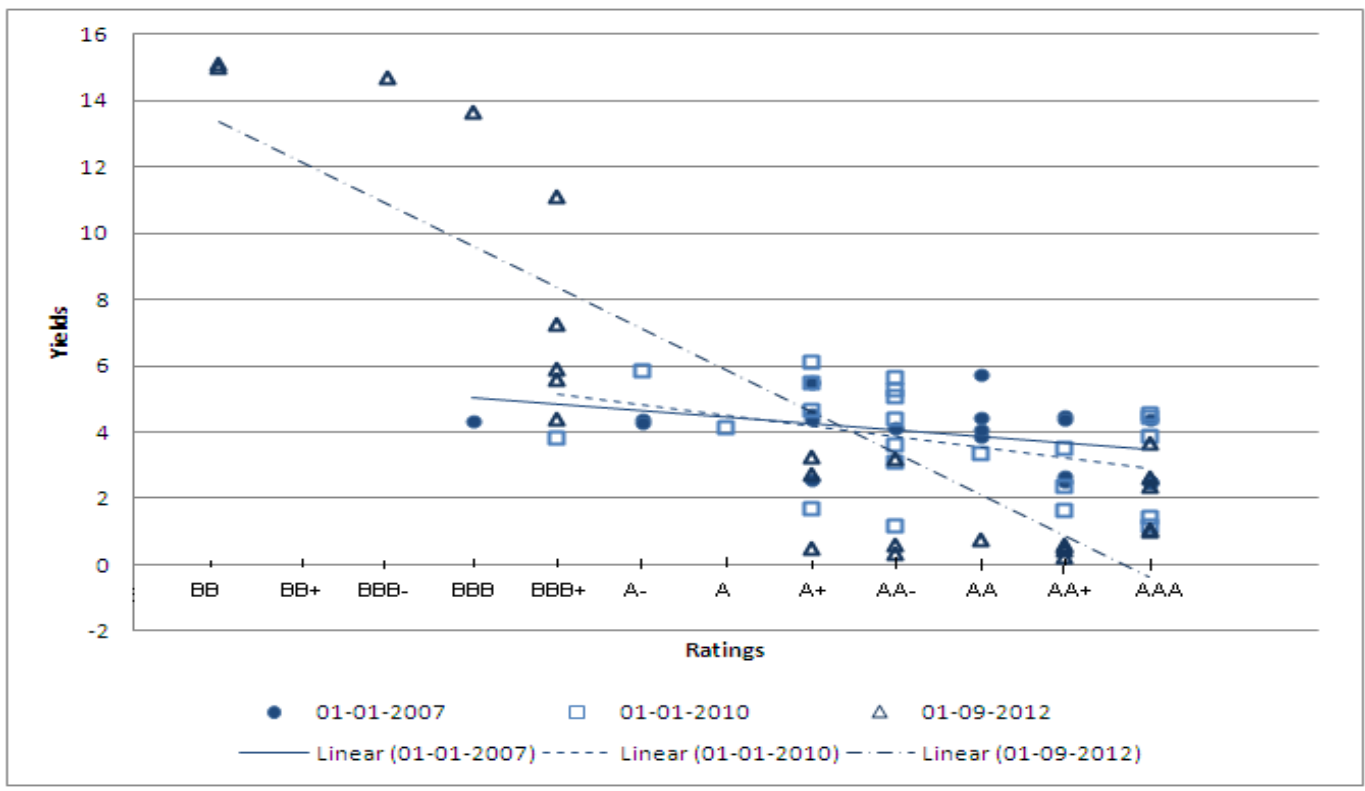

Source: Own calculations based on data from Datastream and S\&P.

\section{Financial health of banks and private actors}

Difficulties faced by banks and private firms further reduce SNGs' fiscal space for public investment. In addition to the factors described above, the fiscal space of SNGs for public investment also depends on the health and fiscal space of other actors, such as banks, investors and public enterprises that could participate in public-private partnership agreements. As SNGs, these actors have also seen their financial room of manoeuvre reduced since the global financial crisis.

Banks, which face increased prudential regulations, ${ }^{19}$ including higher capital requirements, have been reluctant to lend to SNGs or do so at higher rates. In France for example, in 2013, the borrowing needs of SNGs will amount to EUR 17 billion. Banks can only provide about EUR 10 billion, which leaves a deficit of EUR 7 billion to be funded from other sources. The recent collapse of Dexia, a Franco-Belgium bank specialised on the financing of SNGs has increased the borrowing difficulties of SNGs (Box 9). Indeed, in many countries (such as France), SNGs became less interesting clients for banks. Lending to SNGs uses own funds and liquidity, but generate less collateral activities as lending to a private firm would (such as opening a banking account or selling insurance products, etc.).

Some private firms also face financial difficulties, or have more difficulties to obtain bank credit Some SNGs therefore report that the number of firms interested in public-private partnership (PPP) projects has dropped since 2010, and the financial conditions at which enterprises are willing to participate are less and less attractive to SNGs (this is the case in Galicia in particular).

19. New regulations increase own capital requirements for banks, and require them to take into account liquidity. Banks will therefore charge a liquidity premia, in addition to the default premia to the rate they charge SNGs. In additions, banks are required to proceed to "deleveraging", i.e. increasing the ratio of own funds to loans. As increasing own funds is not an option at the moment, they are reducing the volume of their loans to reach the target ratio. 


\section{Box 7. Dexia}

Dexia is a Franco-Belgian financial institution. It was created in 1996 through the merger of the Crédit Communal de Belgique and Crédit Local de France, two institutions whose initial goals were to finance local administrations, respectively in Belgium and in France. The group extended its activities from public finance to retail and commercial banking, asset management and insurance.

After a period of sustained growth between 1996 and 2007, Dexia was severely hit by both the subprime and sovereign debt crises. The group was largely exposed to toxic assets, and through its public finance activity, to European public debt. A first bailout was adopted in May 2009, a second one in October 2011 (organising the dismantlement of the bank and the nationalisation of its Belgium arm, Dexia Banque Belgique), and a third one in December 2011. A new bailout plan was announced by the French and Belgium governments in November 2012.

Dexia was the major institution financing local authorities in France and Belgium (Dexia represented 40\% of loans granted to French localities). Hence, the dismantlement of the group in late 2011 has large consequences on sub-national access to borrowing.

Source: Dexia Credit Local/CCRE.

\section{The impact of recent fiscal policies on SNGs' financial capacity for investment}

Both central and sub-national governments have introduced short-term measures to restore public finances, which often affect SNG fiscal space for public investment. On the revenue side, SNGs try to increase their revenues by increasing tax rates or fighting tax evasion. In some cases, they also cut transfers to lower levels of government or introduce deficit objectives. On the expenditure side, the most common short-run reactions of SNGs were to introduce expenditure cuts.

\section{Raising tax rates and fighting tax evasion}

One way of reducing budget deficits or preserving fiscal space for public investment is to increase revenues. Tax leverage measures include for instance increasing tax rates, eliminating tax exemptions, creating new taxes, changing tax bases or fighting tax evasion.

In countries with some degree of SNG tax autonomy, SNGs have often increased their own taxes (raising the rate or broadening the base) and/or fees to meet fiscal targets. The case of Swedish county councils there is a good example of SNG use of autonomous taxing power to generate extra revenues (Box 10).

\section{Box 8. County Councils in Sweden}

The Swedish case is a good example of the propensity of sub-national governments to increase the rates of their autonomous taxes in difficult economic times.

Sweden is divided into 21 counties (län) in charge of implementing the central government's policies. County councils' revenues are exclusively based on a personal income tax; the regional administration can decide on the tax rate autonomously. Tax rates are however very similar across Swedish county councils.

Since the beginning of the financial crisis most regional authorities have decided to increase the personal income tax rate. The average income tax rate has risen by $0.4 \%$, with large increases for county councils where the initial tax rate was relatively low. Regional governments decided to increase taxes in all but four county councils where the tax rates declined (Stockholm) or remained stable (Dalarnas, Skåne Västerbottens). 
Box 8. County Councils in Sweden (cont.)

Evolution of Swedish County Councils' tax rates

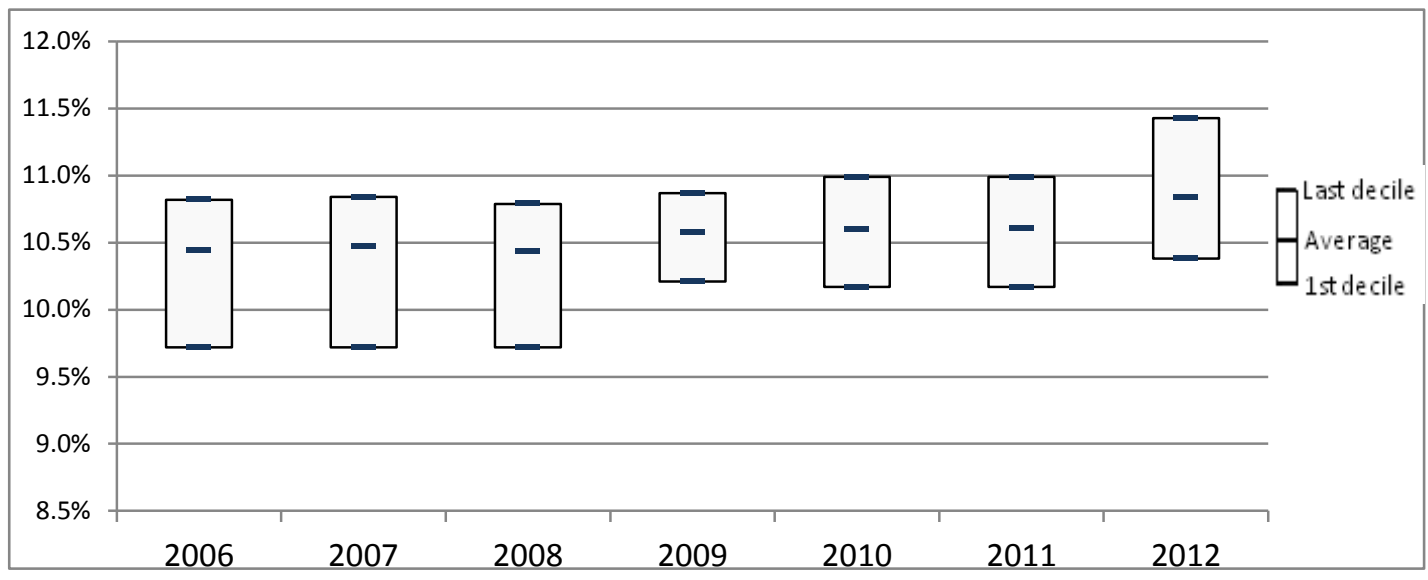

Source: Authors' calculations based on data from the Årsbok för Sveriges kommuner 2012.

Measures to fight tax evasion were also common among SNGs (Box 11). But in a context of stagnant growth, in the short run such measures may not yield the expected revenues.

\section{Box 9. Measures taken by SNGs to increase revenues}

In Belgium, SNGs eliminated tax breaks that had been implemented in previous years. In 2010, the Flemish Community, in particular, abolished a tax cut that had been introduced in 2009 for all workers, aiming to increase the employment rate and increase the financial attractiveness of work ("job korting"). In Spain, autonomous communities and, to a lesser extent, local governments spontaneously increased some taxes, while also taking measures on the spending side. In particular, some autonomous communities increased the rates of taxes on property transactions, personal income tax for high income earners, tax on retail sales of oil products and the duty on specific means of transport (tax on the registration of new vehicles, boats and planes). Some autonomous communities also established new environmental taxes. The movement towards higher taxes in local governments was less pronounced than for the autonomous communities. In this regard, an important measure will be the approval of new real estate values, which will provide higher receipts for the main local tax (tax on real estate property).

Some countries also reported an increase in fees (Austrian municipalities, Greece, English local authorities). While Greek local governments do not have tax autonomy, they can use fees to finance the services they provide.

When SNGs do not have tax autonomy, CGs often balance stricter deficit requirements by increasing the rates or shares of taxes allocated to SNGs, or by giving SNGs greater autonomy in setting the rates. In the Czech Republic, real estate tax rates (exclusive income of municipalities) were doubled under the consolidation measures approved at the end of 2009. The exemption from property tax for new buildings was cancelled in 2010. In addition, municipalities have been allowed to set local coefficients for real estate tax calculation since 2008 (real estate tax is calculated as a combination of surface, real estate tax rate, statutory coefficient and local coefficient). The revenues of municipalities were further augmented by increasing the rates and by extending the tax base for accommodation fees collected by them.

Some SNGs took measures to fight tax evasion. In Ireland, SNGs took initiatives to ensure that all owners of non-principal private residences were paying the appropriate charges. In Spain, autonomous communities developed instruments to reinforce co-operation between the different tax administrations to reduce tax evasion: exchange of information among administrations; sharing fiscal information to improve auditing; and developing software to improve auditing of selected taxpayers. Co-ordination bodies between the central tax administration and sub-national tax administrations also played an important role in fighting tax evasion, specifically in the building industry. In Greece, a 2010 law transferred the monitoring and enforcement of tax and fee collection to the Court of Auditors, who was perceived as a political leaders better qualified than local to carry out this task. In Canada, Quebec - which collects all 


\section{Box 9. Measures taken by SNGs to increase revenues (cont.)}

of its revenues - estimates that it will collect an additional CAD 1.2 billion per year by 2012-14 from measures to combat tax evasion and tax avoidance. The Italian central government tried to increase tax compliance by giving incentives to local governments to fight tax evasion, such as allowing them to keep up to $100 \%$ of the additional sums collected in their territories.

Source: Vammalle and Hulbert (2013).

\section{Expenditure cuts often target investment}

Most countries require SNGs to participate in national fiscal consolidation efforts by introducing budget deficit targets and/or expenditure limits (Table 2). In many cases, CGs have little scope for action on municipalities which tend to be the agents of the regional tier of government. In particular, in some highly decentralised countries, CGs cannot impose deficit targets on SNGs (Germany, although in the process of modifying this legislation; Switzerland); targets are either negotiated between central and state/regional authorities, or imposed by federal entities. Nevertheless, CGs have tried to influence SNG policies to encourage SNGs to return to fiscal balance in the medium term. This is the case in Canada, where all provinces and territories have announced plans to return to balance, with 12 out of 13 jurisdictions committed to doing so by $2014-15$ at the latest. ${ }^{20}$

Table 1. Sub-national government expenditure reduction targets (\% of SNGs revenues)

\begin{tabular}{lcccccc}
\hline & $\mathbf{2 0 1 0}$ & $\mathbf{2 0 1 1}$ & $\mathbf{2 0 1 2}$ & $\mathbf{2 0 1 3}$ & $\mathbf{2 0 1 4}$ & $\mathbf{2 0 1 5}$ \\
\hline Slovak Republic & $-3.45 \%$ & $-3.56 \%$ & $-1.69 \%$ & $-3.15 \%$ & $-4.92 \%$ & \\
United Kingdom (English Local Authorities) & & $-1.20 \%$ & $-0.87 \%$ & $-0.10 \%$ & $-0.68 \%$ & \\
Greece & & & $-2.19 \%$ & $-3.65 \%$ & $-4.67 \%$ & $-6.59 \%$ \\
\hline
\end{tabular}

Source: OECD Fiscal Network questionnaire (Sept-Oct. 2011, January 2012, November 2012 for Spain and Belgium) and

OECD (2013), National Accounts (database), http://dx.doi.org/10.1787/na-data-en (accessed on 26 August 2013).

Local governments were also requested to contribute to consolidation efforts, as regional governments often cut transfers to them. Local governments are responsible for a large share of public investment, and the delivery of crucial public services, and their financial room of manoeuvre is usually more limited than the regional governments' one. This cascade effect may therefore have negative consequences on public service delivery and on public investment.

SNG measures to reduce expenditures often target public investment. As suggested by earlier studies (World Bank, 1988; Vammalle and Hulbert, 2013), public investment seems to be a preferred variable to adjust SNGs budgets. Many consolidation programmes mention explicitly amounts to be saved by reducing public investment (OECD, 2012). This is the case in Austria, Czech Republic, Greece, Iceland, Ireland, Luxembourg, Portugal, Slovak Republic, Slovenia, Spain, Sweden, Switzerland, and the UK. For some of these countries, targeted amounts are very large. For example, Spain planned to reduce investment in infrastructure by $€ 33.54$ billion between 2011 and 2013 (representing 3\% of the $2011 \mathrm{GDP}$ ), and the central government also planned to cut all its other investments by $25 \% .^{21}$ In Greece, planed public investment cuts amount to $€ 40.16$ billion over the

20. Ontario, which has been severely affected by the recession and is expecting only moderate growth going forward, is projecting a return to balance by 2017-18. Alberta is projecting a return to balance as early as 2013-14 (Vammalle and Hulbert, 2013).

21. Questionnaires on Fiscal Consolidation across Levels of Government sent to delegates of the OECD Network on Fiscal Relations across Levels of Government in September-October 2011. 
2011-2015 period (representing 18\% of 2011 GDP). Luxembourg, Portugal, Slovak Republic and Slovenia $^{22}$ also plan severe cuts in public investment.

In contrast, some countries have combined austerity measures with specific strategies to preserve (at least in part) public investment. For example, Estonia, France, and Ireland, have introduced investment plans while carrying out their consolidation strategies. In France, an "investments for the future" program was launched in 2010, and Ireland launched a "Jobs Initiative" in May 2011, including measures to boost R\&D. In the United Kingdom, the government's fiscal mandate protects the most productive capital spending (although considerable cuts in capital spending will still be made). Denmark introduced a fiscal stimulus package in 2012 based on increased public investment. Japan, in a very different context, launched a $¥ 19$ trillion ( $€ 190$ billion, or $3.9 \%$ of 2010 Japanese GDP) plan for recovery and reconstruction after the Great East Japan Earthquake.

Similarly, some CGs tried to protect priority sectors - mainly education, health and social protection - from recent spending cuts. In Estonia, social welfare grants were protected, and in the Slovak Republic, wages in the education sector were preserved. In Italy, the rules of the Internal Stability Pact exempted a number of sectors such as health or projects co-financed by the European Union. In the United Kingdom, earmarked grants for health and education were preserved. Projects co-financed by the European Commission are also often protected from spending cuts (Italy). Nevertheless, when large consolidations are implemented, cuts in sensitive sectors such as education or health can generally not be avoided as they represent the lion's share of SNG expenditure (Spain) (Box 12). ${ }^{23}$

\section{Box 10. Examples of expenditure cuts by SNGs}

The US states started consolidation policies early during the global financial crisis (2008) due to their constitutional obligation to have balanced budgets. They took measures such as cutting personnel and reducing health and social benefits, but also cut their transfers to lower tiers of government, thus creating a cascade effect in local governments of counties, cities, etc. (Vammalle et al., 2012). In Canada, provincial consolidation measures mostly consisted of wage restraint and a payroll freeze for the public service. According to projections in February 2012, the programme spending in 2011-12 was to increase by 3.1\%, well below the annual average growth of $6.3 \%$ observed between 2000-01 and 2010-11. Most provinces also projected that their programme spending would grow by less than $3 \%$ per year throughout their forecast horizons. In Estonia, the central government recommended that operating costs be frozen while allowing investment expenditure to grow, but could not impose this principle on SNGs.

In Galicia (Spain), the regional government tried to preserve the 2010-2011 budgets for education and health, considered as priorities. However, even those sectors are currently affected by austerity measures. Along with the general cut in public wages carried on by the central government, the Galician regional authorities have implemented measures in order to extend teachers' working hours instead of hiring new teachers, and reduced funding of sick leave benefits for public workers. The main adjustment variables used by the regional government in its cuts so far are investment (30\% decrease between 2007 and 2010, while on average Spanish regions decreased their public investment by $43.5 \%$ ) and current and capital transfers to local governments and companies (both public and private).

Source: Vammalle and Hulbert (2013).

22. More details on planed investment cuts by central governments in: OECD (2012), Restoring Public Finances, 2012 Update, OECD Publishing, OECD, Paris.

23. Information from Fiscal Network Questionnaire (Sept-Oct, 2011 and January, 2012). 


\section{Conclusion}

The global financial crisis and ensuing consolidation drive have generated upward pressure on public budgets at the sub-national level. In particular, operating expenditures grew at a much stronger pace than revenues, hence automatically reducing the fiscal space left for public investment. Spending in social benefits and current transfers paid by SNGs (including support to households, companies or other levels of governments) represented the fastest-growing items in sub-national spending. Therefore, economic support from sub-national authorities in the aftermath of the crisis has participated in reducing their fiscal space for investment.

In parallel, sub-national governments' access to borrowing has deteriorated since 2007. Financial markets started discriminating between high and low-risk SNGs, and sub-national authorities perceived as risky saw their yields escalate. Additional prudential requirements for banks, as well as the collapse of Dexia, reduced the willingness of financial intermediates to lend to SNGs. New fiscal rules set at the sub-national level also participated in limiting SNG borrowing in many OECD countries.

Facing cuts in transfers from central authorities on the revenue side, and/or increased operating expenditures on the spending side, many OECD countries implemented measures to restore SNG public finances, including wide cuts in investment spending. Increases in SNG tax revenues or expenditure cuts were introduced in many countries, and further reforms were planned for 2012 onwards. 


\section{REFERENCES}

Aulich C. , G. Sansom and P. McKinlay (2013): "A Fresh Look at Municipal Consolidation in Australia”, Local Government Studies, DOI:10.1080/03003930.2013.775124

Bach, S., Blöchliger, H., Wallau, D. (2008), “The Spending Power of Sub-Central Governments: a PilotStudy", OECD Network on Fiscal Relations across Levels of Government WP No. 8, OECD, Paris, COM/CTPA/ECO/GOV (2009)8.

Balassone, F. and D. Franco (2000), "Public Investment, the Stability Pact and the "Golden Rule”,", Fiscal Studies, Vol. 21.

Belfius (2013a): "Les charges de pension des fonctionnaires locaux".

Belfius (2013b): "Le viellissement de la population".

Bish R. (2011): "Discredited Nineteenth-Century Ideals Alive in the Twenty-First", The Urban Papers N. 150.

Blanchard, O. and G. Giavazzi (2003), "Improving the SGP through a Proper Accounting of Public Investment", European Economic Perspectives Newsletter, Centre for Economic Policy Research, London, www.cepr.org.

Blöchliger, H., King, D., (2006), "Fiscal Autonomy of Sub-Central Governments”, OECD Network on Fiscal Relations across Levels of Government WP No. 2, OECD, Paris, COM/CTPA/ECO/GOV/WP (2006)2.

Blöchliger, H. (2012), "Fiscal consolidation across government levels", paper prepared for the annual meeting of the OECD Network on Fiscal Relations across Levels of Government's in November 2012.

Blöchliger, H. (2012b), "Fiscal rules for sub-central governments. 2011 update of the OECD indicator", paper prepared for the annual meeting of the OECD Network on Fiscal Relations across Levels of Government's in November 2012.

Blöchliger, H., Charbit, C., Pinero Campos, J-M., Vammalle, C. (2010), "Sub-central Governments and the Economic Crisis: Impact and Policy Responses", Economics Department Working Papers No. 752, OECD, Paris, ECO/WKP (2010)8.

Braun, B and Y. Otsuka (1998): "The Effects of Economic Conditions and Tax Structures on State Tax Revenue Flow", International Advances in Economic Research, Vol. 4.

Byrnes J. and B. Dollery (2002): "Do Economies Of Scale Exist In Australian Local Government? A Review Of The Empirical Evidence", University of New England Working Paper Series in Economics.

De Haan, J., Sturm, J.E. and B.J. Sikken (1996), Government Capital Formation: Explaining the Decline, Weltwirtschaftliches Archiv 132, 55-74.

DEXIA (July 2012), Finances publiques territoriales dans l'Union européenne. 
Dollery B., J. Byrnes and L. Crase (2008): "Structural Reform in Australian Local Government", Australian Journal of Political Science, 43:2, 333-339.

Felix, A (2008),"The Growth and Volatility of State Tax Revenue Sources in the Tenth District", Federal Reserve Bank of Kansas City Economic Review.

Fritz (2011): "Fiscal Effects of Municipal Amalgamation", Paper prepared for the 15th Annual Conference of The International Society for New Institutional Economics 2011.

Gentry W. and H Ladd (1994): "State Tax Structure And Multiple Policy Objectives", National Tax Journal, Vol. 47.

Geys B., F. Heinemann and A. Kalb (2007): "Local Governments in the Wake of Demographic Change: Efficiency and Economies of Scale in German Municipalities", ZEW Discussion Papers, No. 07-036

Harmon, O. and R. Mallick (1994): “The Optimal State Tax Portfolio Model: An Extension”, National Tax Journal.

Hayashi M. (2006), "Redistribution and Local Governments in Japan”, Policy Research Institute Financial Review, Vol. 82.

Heller, P. (2005): “Understanding Fiscal Space”, IMF Policy Discussion Paper PDP/05/4.

Hooghe, L., Marks, G. And Schakel, A-H. (2010), "The Rise of Regional Authority. A Comparative Study of 42 Democracies", Routledge, New York, USA.

Kelley D. (2012): “The political economy of unfunded public pension Liabilities”, Public Choice.

Marcel, M. (forthcoming): "Budgeting For Fiscal Space And Government Performance Beyond The Great Recession”.

Moisio and Uusitalo (2003): "Kuntien yhdistyrnisten vaikutukset kuntien menoihin" [Effects of Municipal Mergers on Municipal Spending], Finnish Ministry of the Interior.

Nakazawa N. and T. Miyashita (2013): "Does the method adopted for distribution of services by amalgamating municipalities affect expenditure after amalgamation? Evidence from Japan", Joint Discussion Paper Series in Economics.

Norregaard, J. (2013): “Taxing Immovable Property Revenue Potential and Implementation Challenges", IMF Working Paper No. 13/129.

OECD (2011a), OECD Regional Outlook 2011: Building resilient regions for stronger economies, OECD Publishing, Paris, http://dx.doi.org/10.1787/9789264120983-en.

OECD (2011b), Making the Most of Public Investment in a Tight Fiscal Environment: Multi-level Governance Lessons from the Crisis, OECD Publishing, Paris, http://dx.doi.org10.1787/9789264114470-en.

OECD (2012), Restoring Public Finances 2012Update, OECD Publishing, Paris, http://dx.doi.org10.1787/9789264179455-en. 
Olejaz M, J. Annegrete, A. Rudkjøbing, H. Okkels Birk, A. Krasnik and C. Hernández-Quevedo (2012): "Denmark Health System Review", Health Systems in Transition, Vol. 14.

Ostry, J. D., Ghosh, A. R., Kim, J. I., and M.S Qureshi (2010), Fiscal space, IMF Staff Position Paper, SPN/10/11.

Piñero Campos, J-M., and C. Vammalle (2011), "Financial resources, expenditures and debt of subcentral governments", in: Institutional and Financial Relations across Levels of Government in a Tight Fiscal Context, KIPF/OECD Publication.

Reingewertz Y. (2013): "Do municipal amalgamations work? Evidence from municipalities in Israel", Journal of Urban Economics, Vol. 72.

Seegert, N. (2012): “Tax-revenue Volatility”, unpublished.

Schunk D. and S. Porca (2005): "State-Local Revenue Diversification, Stability, and Growth: Time Series Evidence", The Review of Regional Studies, Vol. 35.

Slack E. and R. Bird (2013): "Does Municipal Amalgamation Strengthen the Financial Viability of Local Government? A Canadian Example", International Center for Public Policy Working Paper Series.

Standard \& Poor's (2010), "Methodology for Rating International Local and Regional Governments", Global Credit Portal, RatingsDirect.

Strandberg-Larsen M., M. Bernt Nielsen, A. Krasnik and K. Vrangbæk (2006): "Is Denmark prepared to meet future health care demands?", Eurohealth Vol. 12.

Vammalle, C., C. Hulbert and R. Ahrend (2014), "Financing Investment for Growth: A sub-national perspective. Part II: Creating Fiscal Space for Public Investment: The Role of Institutions", OECD Regional Development Working Papers, 2014/02, OECD Publishing.

Vammalle, C. and C. Hulbert (2013), "Sub-National Finances and Fiscal Consolidation: Walking On Thin Ice", OECD RDP WP.

Vammalle, C., D. Allain-Dupré and N. Gaillard (2011), “A sub-central government perspective on fiscal policy in a tight fiscal environment" in $\mathrm{OECD} / \mathrm{KIPF}$, Institutional and Financial Relations across Levels of Government, OECD Publishing, Paris, doi:10.1787/9789264167001-3-en.

World Bank (1988), “World Development Report 1988”, World Bank, Washington DC. 


\section{ANNEX 1 - EVOLUTION OF THE COMPONENTS OF SNG REVENUES}

\section{Evolution of SNGs' own revenues}

SNGs in federal and highly decentralised countries tend to have a higher own revenue-to-GDP ratio, as their total revenues represent a larger share of GDP than in centralised countries. This ratio is also high in countries where SNGs are mostly financed through tax revenues, such as Sweden, Finland or Denmark. In most countries the decline in direct financing capacity does not seem to be linked to the evolution of own revenues. At the aggregated level, own revenues per capita and the SNG own revenues-to-GDP ratio have proven rather resilient to the recent crisis, with only a very limited decline between 2009 and 2010 (Figures 15 and 16). This stability may be explained by the revenue mix of SNGs and the effects of fiscal equalisation systems, which are intended to be as stable as possible. Reforms to increase the share of SNGs shared taxes were also passed in a few countries. Increases in taxes or user fees introduced in many consolidation packages may also have had a stabilising impact on own revenues. However, in some countries (Australia, Denmark, Hungary, Iceland, Korea, Spain), own revenues per capita declined significantly over the period, therefore affecting negatively the DFC ratio. Hence there are large disparities in the evolution of own revenues across OECD countries.

Figure 26

SNG own revenues (\% of GDP)

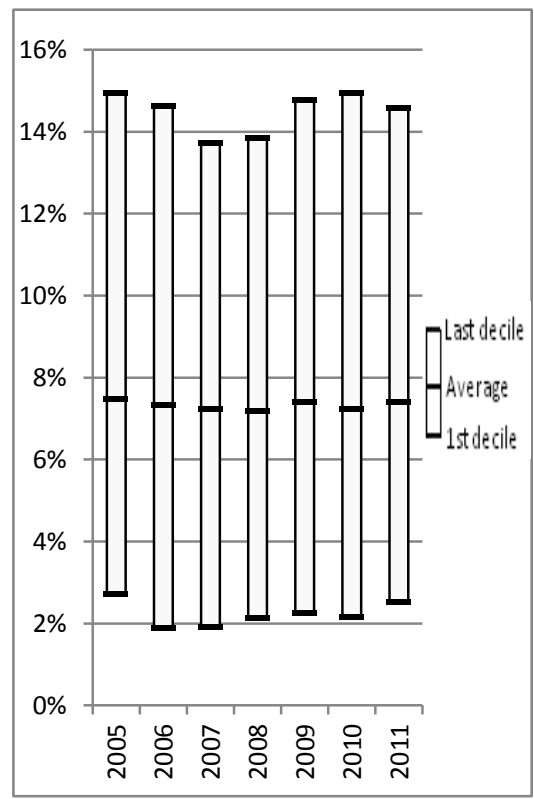

Source: OECD (2013), National Accounts (database), http://dx.doi.org/10.1787/na-data-en (accessed on 26 August 2013). Note: No data for Chile. Data for Canada, Korea, New Zealand: 2010 instead of 2011. Turkey from 2006 to 2010.
Figure 27. SNG own revenues per capita In constant (2005) USD

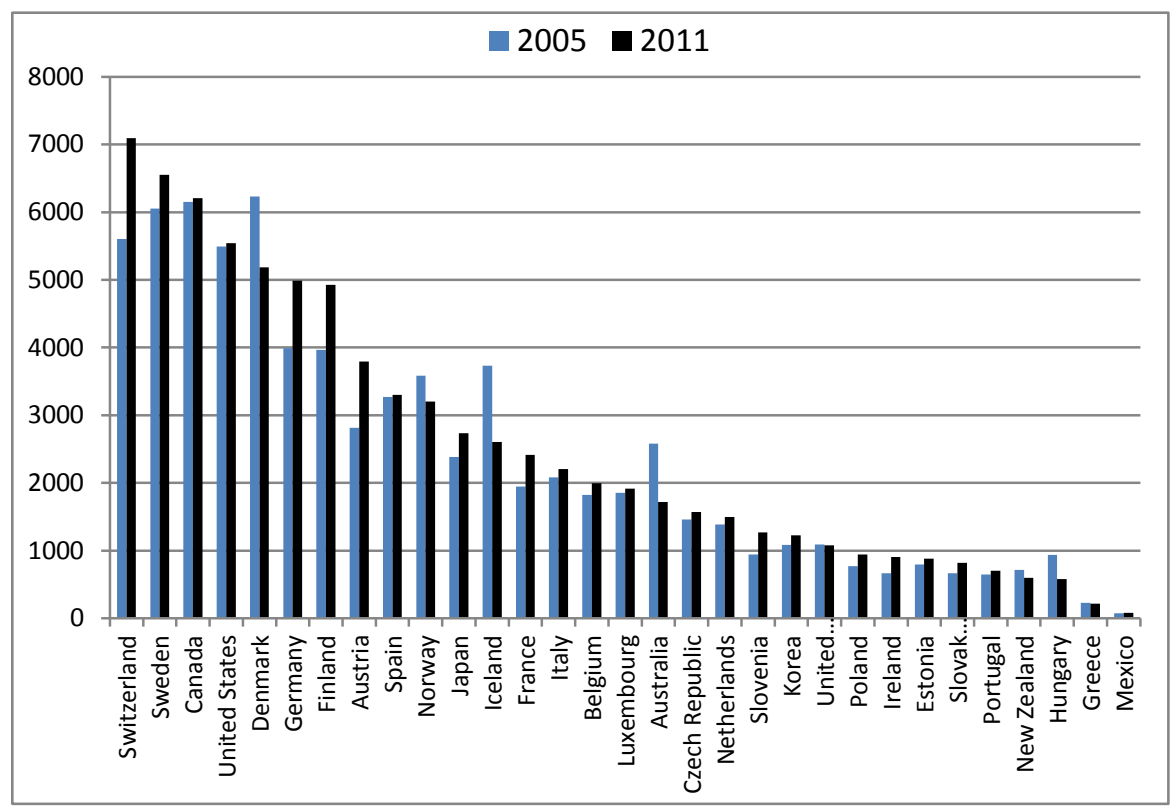

Source: OECD (2013), National Accounts (database), http://dx.doi.org/10.1787/na-data-en (accessed on 26 August 2013).

Note: Data for Australia, Canada, Korea, Luxembourg, Mexico and New Zealand: 2010 instead of 2011. Population for Denmark and Spain: 2010 instead of 2011. 


\section{Evolution of current transfers}

The decline in SNG direct financing capacity does not appear to be linked to the evolution of current transfers received. Probably in mainly due to central governments' increased current transfers to SNGs as a response to the global financial crisis, current transfers rose between 2007 and 2011 (Figures 17 and 18) in all countries but Austria, Iceland, Spain and the UK, while the average level of current transfers-to-GDP ratio started to fall in 2011, after reaching a peak in 2010. Current transfers per capita in 2011 were still $25 \%$ higher than their 2007 value at the local level, and $11 \%$ higher at the states/regional level.

Figure 28. Evolution of current transfers (\% of GDP)

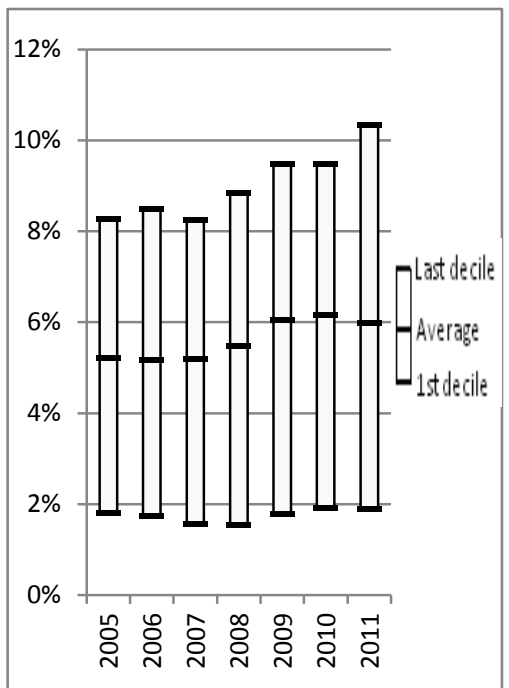

Source: OECD (2013), National Accounts (database), http://dx.doi.org/10.1787/na-data-en (accessed on 26 August 2013).
Figure 29. Evolution of current transfers per capita

In constant (2005) USD

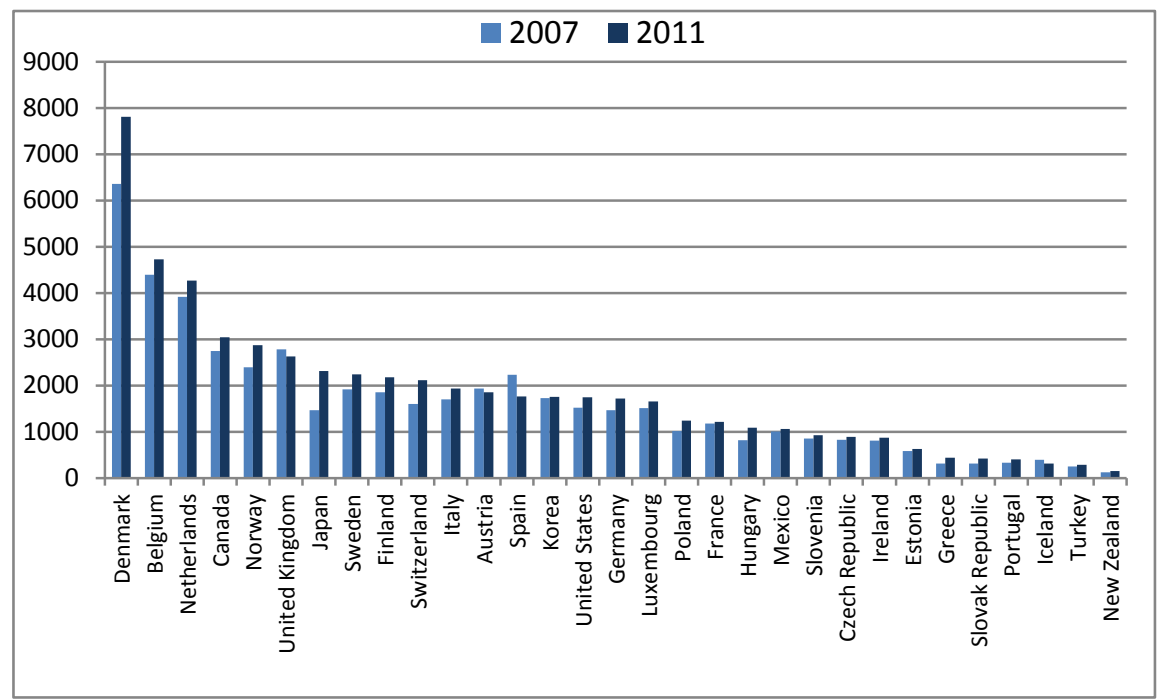

Source: OECD (2013), National Accounts (database), http://dx.doi.org/10.1787/na-dataen (accessed on 26 August 2013).

\section{Evolution of capital transfers}

Capital transfers is the only revenue variable which declined on average over the 20072011period (Figure 19). In particular, capital transfers per capita to local authorities dropped by $4 \%$ between 2007 and 2011 - although capital transfers to states/regions increased by $2.5 \%$. Disparities in the evolution of transfers are particularly high among OECD countries, with those countries severely affected by the economic crisis enacting drastic reductions in capital transfers (Ireland, Spain, Italy for example) (Figures 19 and 20). Box 4 presents examples of reductions in capital transfers in Italy and Spain. 
Figure 30. Evolution of capital transfers (\% of GDP)

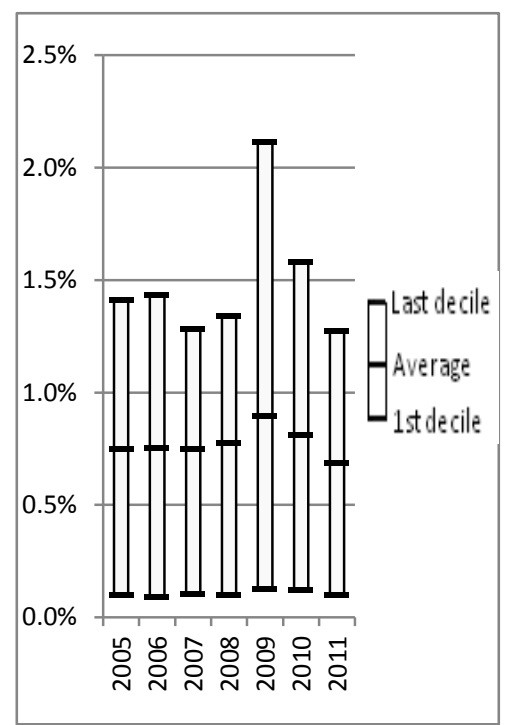

Source: OECD (2013), National Accounts (database),

http://dx.doi.org/10.1787/na-data-en (accessed on 26 August 2013).
Figure 31. Evolution of capital transfers per capita

In constant (2005) USD

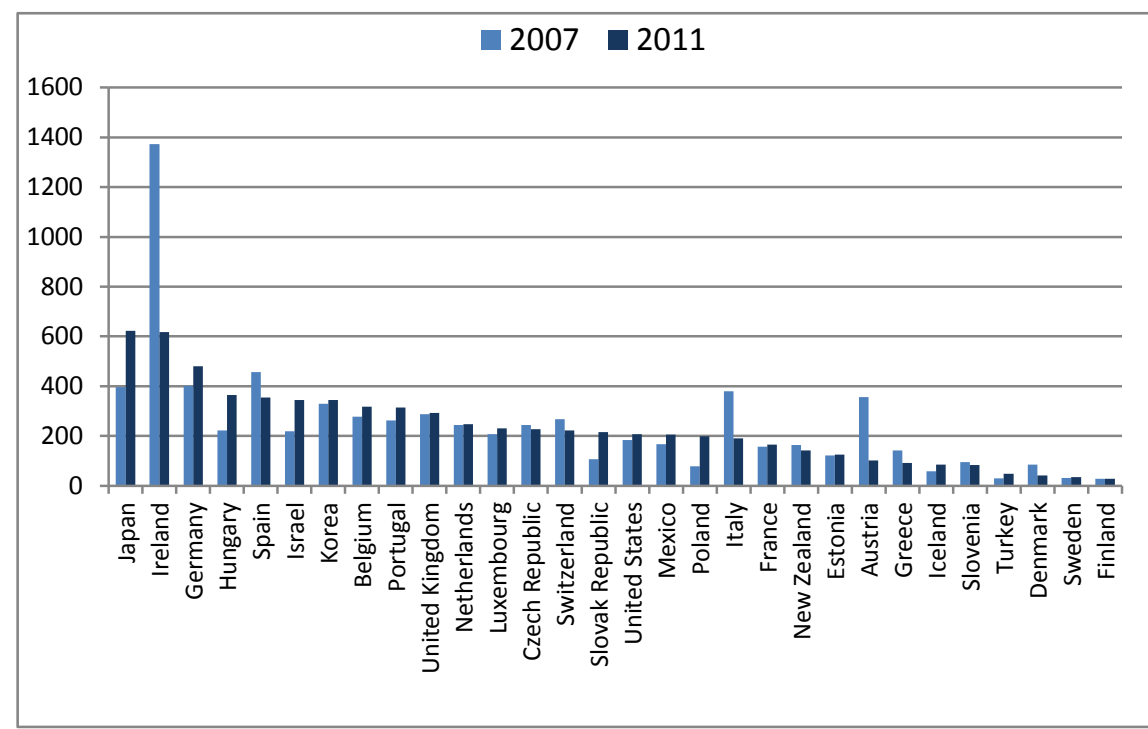

Source: OECD (2013), National Accounts (database), http://dx.doi.org/10.1787/na-data-en (accessed on 26 August 2013).

\section{Box 11. Evolution of capital transfers in Italy and Spain}

Capital transfers to Italian regions and local authorities declined by 30\% on average between 2007 and 2010 . These reductions were not applied evenly to all regions; in particular, transfers to the regions of Abruzzo, Emilia Romagna and Friuli Venezia Giulia declined by nearly $70 \%$ over the period, whereas they remained stable for Lombardia.

\section{State capital transfers to Italian regions per capita} In constant (2005) Euros

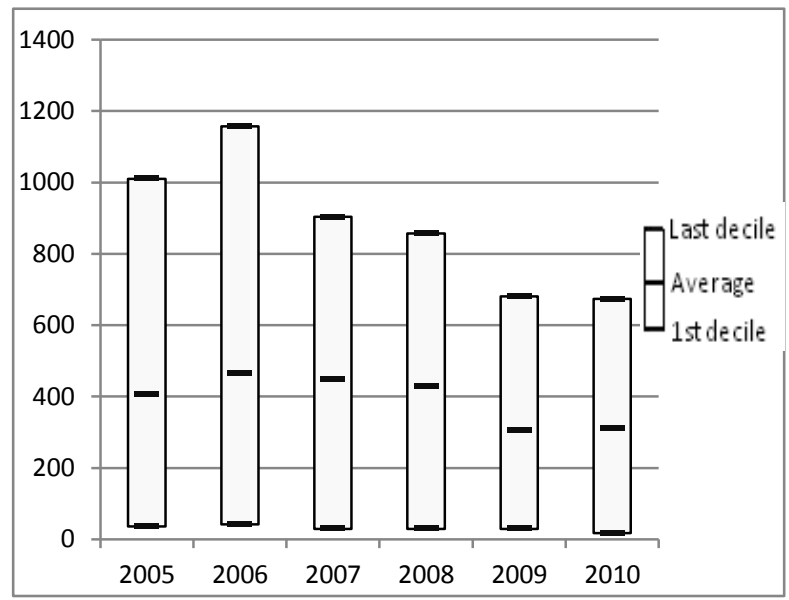

State capital transfers to Italian local authorities p.c. In constant (2005) Euros

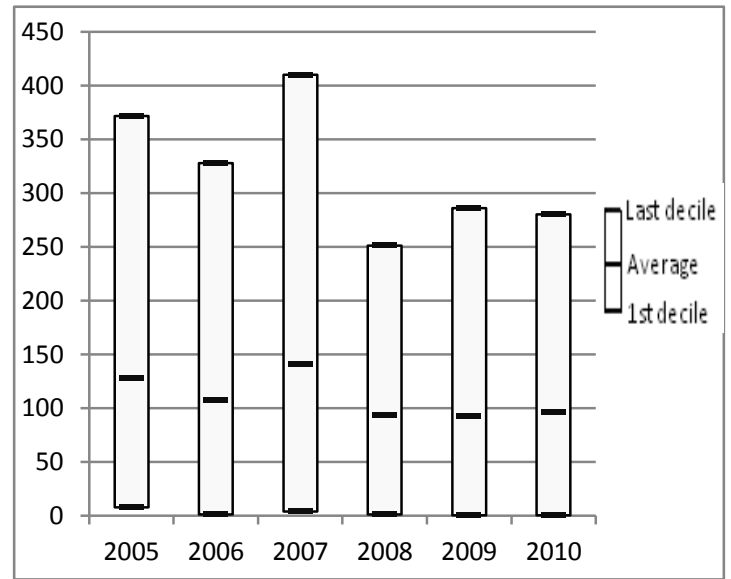

Note: data are aggregated per region.

Source: Author's calculations based on data from the Conti Pubblici Territoriali. 


\section{Box 11. Evolution of capital transfers in Italy and Spain (cont.)}

Regions receiving large levels of capital transfers per capita were comparatively less affected. In particular, transfers to Puglia and Sicilia (the only two Italian regions receiving more than 1000 euros per capita in capital transfers from the $\mathrm{CG}$ ) declined by $25 \%$, i.e. less than the average region. This evolution reduced drastically the overall disparity between Italian regions.

Although state capital transfers to local authorities are much smaller than those granted to regions, reductions also affected Italian SNGs in an unequal fashion. For example, capital transfers per capita to local authorities in Abruzzo and Valle d'Aosta declined by more than $80 \%$ over $2007-2010$, while they remained constant in Calabria, Emilia Romagna and Lombardia.

\section{Galicia, Spain}

The particular case of Galicia is a good illustration of the evolution of capital transfers in Spanish ACs. Capital transfers granted by Galicia to local authorities and companies were cut by $61 \%$ between 2007 and 2010 , which was followed by a sharp drop in regional public investment. Such a sharp reduction in transfers to local authorities could generate a large contraction of investments at the municipal level. This impact is essential since municipal investment accounts for more than the double of the investment by the region. In addition, cuts in capital transfers to private and public companies could further affect both private and public investment (see Figure below).

\section{Capital transfers granted by the Galicia region, per capita} In constant (2005) Euros

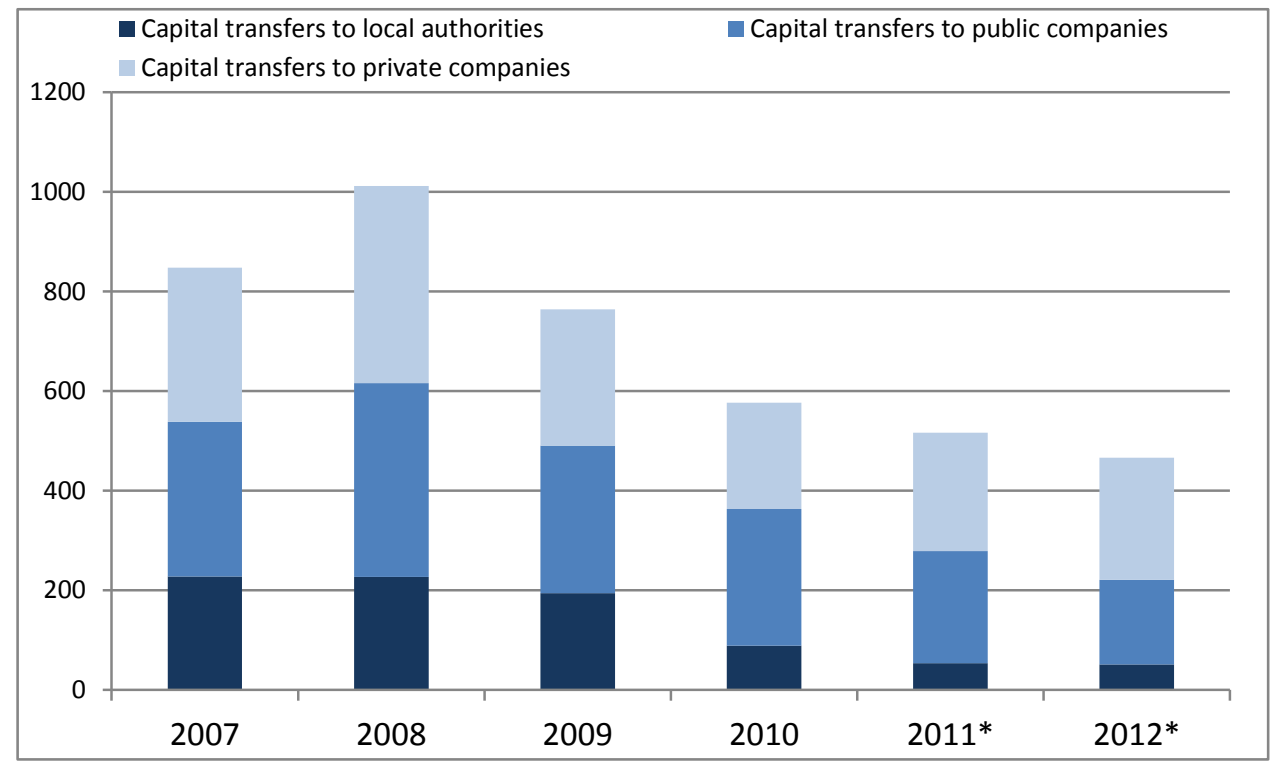

Note: * Planned values for 2011 and 2012.

Source: Regional finances case study: Galicia. 